\title{
Rules and Exceptions: The Role of Chromosomal ParB in DNA Segregation and Other Cellular Processes
}

\author{
Adam Kawalek ${ }^{\dagger} \mathbb{D}$, Pawel Wawrzyniak ${ }^{\dagger}$, Aneta Agnieszka Bartosik and Grazyna Jagura-Burdzy * \\ Department of Microbial Biochemistry, Institute of Biochemistry and Biophysics, Polish Academy of Sciences, \\ Pawińskiego 5a, 02-106 Warsaw, Poland; a.kawalek@ibb.waw.pl (A.K.); wawrzyniakp@ibb.waw.pl (P.W.); \\ anetab2@ibb.waw.pl (A.A.B.) \\ * Correspondence: gjburdzy@ibb.waw.pl; Tel.: +48-225921212 \\ † These authors contributed equally to this work.
}

Received: 4 December 2019; Accepted: 9 January 2020; Published: 11 January 2020

\begin{abstract}
The segregation of newly replicated chromosomes in bacterial cells is a highly coordinated spatiotemporal process. In the majority of bacterial species, a tripartite ParAB-parS system, composed of an ATPase (ParA), a DNA-binding protein (ParB), and its target(s) parS sequence(s), facilitates the initial steps of chromosome partitioning. ParB nucleates around parS(s) located in the vicinity of newly replicated oriCs to form large nucleoprotein complexes, which are subsequently relocated by ParA to distal cellular compartments. In this review, we describe the role of ParB in various processes within bacterial cells, pointing out interspecies differences. We outline recent progress in understanding the ParB nucleoprotein complex formation and its role in DNA segregation, including ori positioning and anchoring, DNA condensation, and loading of the structural maintenance of chromosome (SMC) proteins. The auxiliary roles of ParBs in the control of chromosome replication initiation and cell division, as well as the regulation of gene expression, are discussed. Moreover, we catalog ParB interacting proteins. Overall, this work highlights how different bacterial species adapt the DNA partitioning ParAB-parS system to meet their specific requirements.
\end{abstract}

Keywords: ParB; segrosome; chromosome segregation; cell division; gene expression regulation; partitioning proteins

\section{Introduction}

Bacterial genomes consist of circular or linear and single or multiple chromosomes as well as extra-chromosomal elements like plasmids. They are highly compact spatially and temporally organized entities [1-4]. Chromatin organization is linked to processes such as DNA replication and chromosome segregation and transcription [1,5-9]. In dividing cells, a bi-directional, semi-conservative replication initiated from oriC proceeds simultaneously with the segregation of compacted daughter nucleoids. Specific factors, such as DNA supercoiling, and proteins, such as nucleoid associated proteins (NAPs), determine, maintain, and modify the spatial organization of bacterial nucleoids during the entire cell cycle, from the initiation of replication to the end of the division cycle (reviewed in $[2,10-12])$.

Bacterial genomes are divided into macrodomains $0.5-1.5 \mathrm{Mbp}$ in size, with the ori domain (up to $20 \%$ of the genome around the origin of replication oriC) and ter domain (part of the chromosome around the terminus of replication) playing pivotal roles [13-18]. A chromosome interaction map constructed for Caulobacter crescentus revealed that its genome is additionally split into 23 self-interacting regions of 30-400 kbp, designated chromosome interacting domains (CID) [9]. A similar number of CIDs ranging in size from 50 to $300 \mathrm{kbp}$ were identified in the Bacillus subtilis genome [16]. The boundaries of CIDs frequently co-localize with highly transcribed genes [9,19-22]. The role of NAPs in chromosomal long- 
and short-range interactions $[4,23,24]$ and among them, the structural maintenance of chromosome proteins (SMCs and MukBs) [25-28], has been widely documented. In Mycoplasma pneumoniae, 10-15 kb microdomains with similar gene expression patterns were identified [29].

Chromosomes in most rod-like bacteria, including B. subtilis, C. crescentus, Pseudomonas aeruginosa, Vibrio cholerae, and Myxococcus xanthus, adopt longitudinal organization. In this arrangement, the two replication arms align along the long axis of the cell, whereas the ori and ter domains locate at opposite cell ends $[9,16,28,30,31]$. The left and right arms are thought to wrap around each other, leading to a juxtaposition of the corresponding fragments of opposite chromosome arms [32-34]. The Escherichia coli chromosome exemplifies a transversal configuration, with the ori and ter localized in the middle of the cell and the two replication arms occupying distinct cell halves $[17,35,36]$. The dynamic and species-specific movements of particular chromosomal regions suggest that different factors may be involved in their organization and spatiotemporal segregation.

In this review, we summarize our current understanding of chromosomal ParAB-parS partition systems, which are involved in ori positioning in many species. We focus on the diverse roles of the ParB component and present recent advances in the ParB nucleoprotein complex formation, its involvement in DNA segregation, and other more specialized functions. Moreover, we catalog ParB interacting proteins from various species, which indicates that the biological roles of ParAB-parS systems may extend far beyond the chromosome segregation process.

\section{ParAB-parS-Driven DNA Segregation-From Plasmids to Chromosomes}

The accurate distribution of genetic material in bacteria was initially studied for low-copy-number plasmids, which secure their maintenance in the bacterial population by active DNA partition processes [37-40]. The vast majority of such plasmids uses three component Par systems built from an operon encoding an NTPase (A component, "motor protein") together with a DNA-binding protein (B component), as well as parS, a centromere-like DNA sequence [41-43]. NTPases belong to Walker-type ATPases (partition system of Class I, ParA superfamily) [44,45], actin-like ATPases (Class II) [46], or tubulin-like GTPases (Class III) [47]. The B components use either helix-turn-helix (HTH) (ParB family) [48-51], ribbon-helix-helix (RHH) [52-54], or winged HTH motifs [55] for DNA binding to parS: specific inverted or direct sequence repeats occurring in a single or multiple copies in the plasmid genomes. Despite the structural variability of ParAB-parS elements between plasmids, the main steps of active plasmid partition are conserved. The B component specifically binds to parS site(s) and forms a nucleoprotein complex called a segrosome. The segrosome attracts NTPase, which, in turn, actively separates segrosome pairs by moving individual segrosomes towards the poles of dividing cells [56]. This cellular localization assures that each progeny cell will obtain at least one copy of the plasmid DNA (reviewed in [15,57]).

Studies on plasmid partition received special attention when the sequencing of bacterial genomes revealed oriC proximal operons encoding Class Ia plasmidic orthologs, ParAs, Walker-type ATPases, and ParBs, large proteins with a central HTH motif [41,58-60]. The third element, the variable plasmid-specific sequence(s), are replaced by a highly conserved palindromic parSs, mainly TGTTNCACGTGAAACA, present in varying numbers in the vast majority of single chromosomes, as well as the primary chromosomes of multipartite bacterial genomes (Table 1). To date, par genes have not been found in the chromosomes of the two families of $\gamma$-proteobacteria, Enterobacteriaceae (e.g., E. coli) and Pasteurellaceae (e.g., Haemophilus influenzae), or in one family of Mollicute, Mycoplasmataceae (e.g., Mycoplasma sp). Moreover, a few species seem to miss particular par elements (e.g., Streptococcus pneumoniae lacks parA) [41,59].

The homology between the chromosomal and low-copy-number plasmid counterparts of ParA and ParB families implicates their participation in DNA segregation. Indeed, chromosomal par operons accompanied by a single parS site from the same genome were shown to stabilize otherwise unstable plasmids and Par proteins were able to correctly position the plasmids even within heterologous host 
cells [61-64]. Undoubtedly the chromosome segregation process faces more spatiotemporal challenges than the partition of small plasmid genomes.

The segregation of simultaneously replicating chromosomes proceeds in a few stages. The newly duplicated ori domains are re-folded and pushed away, directed, and held at certain cellular positions. The bulk of chromosome arms follows them, and finally, the ter domains become physically separated [2,65-67]. Studies on the role of ParAB-parS systems have revealed their engagement in ori domain compaction, directional movements, and specific positioning in the cell until cell division (Figure 1), in a species-specific manner. These systems are indispensable in some species, such as C. crescentus or M. xanthus, and are an accessory in the majority of other species (Table 1).
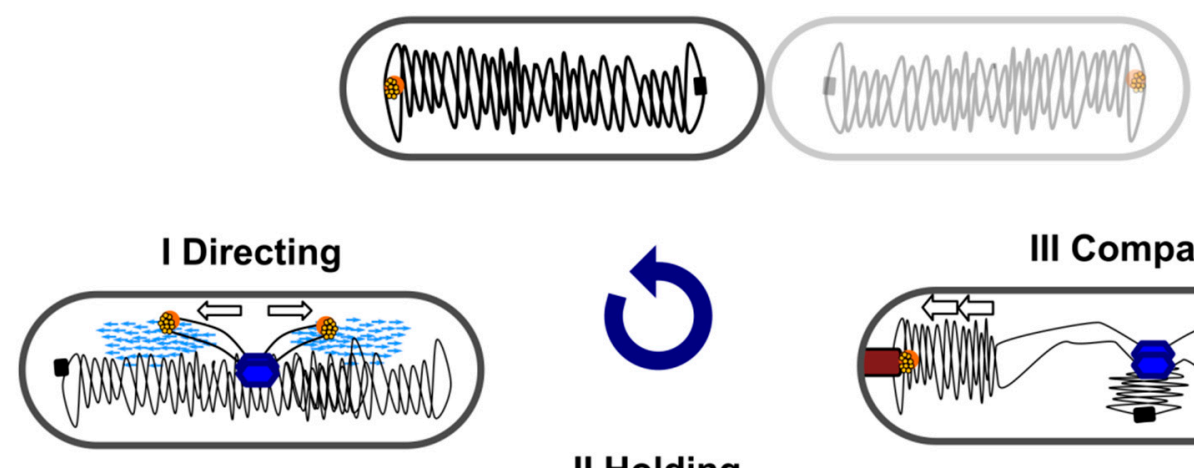

III Compaction

\section{Holding}
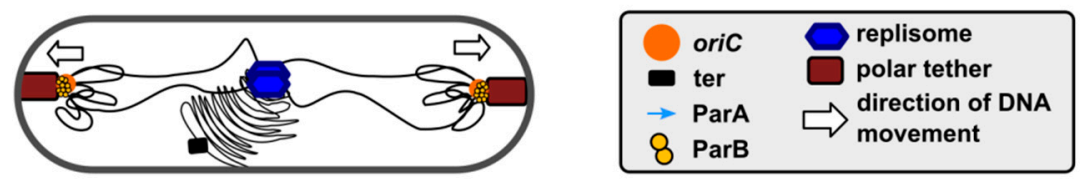

Figure 1. Involvement of partition ParB protein in ori domain re-locations, structuring and positioning during bacterial cell cycle.simplified scheme for $P$. aeruginosa-like longitudinal chromosome rearrangements is presented, in which the replisome is located in the cell centre, and the ParB-bound ori domains are anchored close to the cell poles before division [30]. 
Table 1. Characterization of chromosomally encoded par systems.

\begin{tabular}{|c|c|c|c|c|}
\hline Species & $\begin{array}{l}\text { parS Sites Total/in ori } \\
\text { Domain/Consensus }\end{array}$ & par Genes & Anucleate Cells in parB Mutant & Other Phenotypes associated with Mutation in parB Gene \\
\hline \multicolumn{5}{|c|}{ Gram-positive: } \\
\hline \multicolumn{5}{|c|}{ Firmicutes } \\
\hline Bacillus subtilis & 10/8/TGTTNCACGTGAAACA [68] & non-essential & $1 \%-2 \%$ (wt $0.02 \%$ ) [69] & $\begin{array}{c}\text { Defect in sporulation, elongated cells, increased amount of DNA per cell } \\
\text { overreplication: }>2 \text { foci corresponding to ori in } 35.4 \% \text { cells (wt } 15.3 \% \text {, } \\
\text { disturbed replication control and ori separation [70], impaired SMC } \\
\text { loading (lack of foci) [6] }\end{array}$ \\
\hline Streptococcus pneumoniae & 4/4/AGTTTCACGTGAAACT [71] & $\begin{array}{l}\text { non-essential, } \\
\text { no parA }\end{array}$ & $0.8 \%$ at $30^{\circ} \mathrm{C}$ to $3.5 \%$ at $37^{\circ} \mathrm{C}$ (wt $0 \%$ ) [71] & $\begin{array}{l}\text { No apparent growth defects, mild perturbations in chromosome } \\
\text { segregation, decreased SMC loading near origin [71] }\end{array}$ \\
\hline \multicolumn{5}{|c|}{ Actinobacteria } \\
\hline $\begin{array}{l}\text { Corynebacterium } \\
\text { glutamicum }\end{array}$ & 10/10/TGTTNCACGTGAAACA [72] & non-essential & $\begin{array}{l}43.8 \% \text { in MMI medium, } 11.6 \% \text { in LB (wt } \\
0 \% \text { ) [73] }\end{array}$ & $\begin{array}{l}\text { Reduced growth rate in MMI medium, growth not affected in an LB } \\
\text { medium, altered cell morphology (almost "coccoid" cells and elongated } \\
\text { anucleate cells) [73], impaired SMC loading (lack of visible foci) [72] }\end{array}$ \\
\hline Mycobacterium smegmatis & 3/3/GTTTCACGTGAAAC [74] & non-essential & $10.3 \%$ (wt $0.8 \%)[74]$ & $\begin{array}{l}\text { Elongated cells, overreplication, disturbed septa formation, origin } \\
\text { positioning, and chromosomal topology [75] }\end{array}$ \\
\hline Streptomyces coelicolor & 21/21/tGTTTCACCTGAAACa [76] & non-essential & $\begin{array}{c}13 \%-17.4 \% \text { anucleate spores (wt } \\
1 \%-2 \%)[77,78]\end{array}$ & $\begin{array}{c}\text { Disturbed sporulation, reduced growth rate, elongated cells, premature } \\
\text { and irregular Z-ring formation [79] }\end{array}$ \\
\hline \multicolumn{5}{|c|}{ Gram-negative: } \\
\hline \multicolumn{5}{|c|}{ Alphaproteobacteria } \\
\hline Caulobacter crescentus & 5/5/t/cGTTt/cCACGTGAAAca [80,81] & essential & & $\begin{array}{l}\text { Indispensable, severe chromosome segregation defects, ParB depletion } \\
\text { results in defective Z-ring formation and cell division, formation of long } \\
\text { polyploid cells [82] }\end{array}$ \\
\hline Hyphomonas neptunium & 2/2/TGTTTCACGTGAAACA [83] & essential & anucleate buds [83] & $\begin{array}{c}\text { parB mutants could not be obtained, depletion of ParA blocks cell } \\
\text { division [83] }\end{array}$ \\
\hline \multicolumn{5}{|c|}{ Betaproteobacteria } \\
\hline Burkholderia cenocepacia & $\begin{array}{l}\text { chrI: 2/2/tGTTNCACGTGAAACa chrII: } \\
\text { 6/6/gTTTATGCGCATAAAc [84-87] }\end{array}$ & non-essential & $\begin{array}{l}1-14 \% \text { (depending on mutated } \\
\text { system) [85] }\end{array}$ & $\begin{array}{c}\text { Reduced growth rate, reduction in cell size, compromised viability, } \\
\text { defects in ori positioning [85] }\end{array}$ \\
\hline \multicolumn{5}{|c|}{ Deltaproteobacteria } \\
\hline Myxococcus xanthus & 22/22/TGTTCCACGTGGAACG [88] & essential & $\begin{array}{l}\text { ParB depletion: } 1 \% \text { after } 24 \mathrm{~h}, 10.1-21.6 \% \\
\text { after } 36-48 \mathrm{~h}[88]\end{array}$ & $\begin{array}{c}\text { ParB depletion: aberrant cell morphology, anomalies in DNA segregation } \\
\text { and cell death [88] }\end{array}$ \\
\hline \multicolumn{5}{|c|}{ Gammaproteobacteria } \\
\hline Pseudomonas aeruginosa & $\begin{array}{l}\text { 9/4/TGTTCCACGtGGAACa half-parSs } \\
\text { GTTCCAC or GTTTCAC [89-91] }\end{array}$ & non-essential & $\begin{array}{l}2-4 \% \text { in LB medium, to } 7 \% \text { in an M9 } \\
\text { medium }(w t<0.01 \%) \text { [92] }\end{array}$ & $\begin{array}{c}\text { Reduced growth rate, } 10-15 \% \text { increase in cell size and } 10 \% \text { longer } \\
\text { generation time, altered colony morphology, affected motility; decreased } \\
\text { ParA stability [92] }\end{array}$ \\
\hline
\end{tabular}


Table 1. Cont.

\begin{tabular}{|c|c|c|c|c|}
\hline Species & $\begin{array}{l}\text { parS Sites Total/in ori } \\
\text { Domain/Consensus }\end{array}$ & par Genes & Anucleate Cells in parB Mutant & Other Phenotypes associated with Mutation in parB Gene \\
\hline \multicolumn{5}{|c|}{ Gram-positive: } \\
\hline Pseudomonas putida & ?*/3 TGTTCCACGTGGAACA [63] & non-essential & $\begin{array}{l}5-10 \% \text { in minimal medium during the } \\
\text { transition from exponential to stationary } \\
\text { phase [93] }\end{array}$ & $\begin{array}{c}\text { Defects in chromosome partitioning, abnormal cell morphologies during } \\
\text { the deceleration phase of growth independent of the medium } \\
\text { used }[63,93]\end{array}$ \\
\hline Vibrio cholerae & $\begin{array}{l}\text { chrI: 3/3/NGTTNCACGTGAAACN chrII: } \\
\text { 10/9/NTTTACANTGTAAAN [94] }\end{array}$ & $\begin{array}{l}\text { non-essential } \\
\text { chr1 essential } \\
\quad \text { chr2 }\end{array}$ & no change in parB1 mutant [95] & $\begin{array}{l}\text { Increased frequency of replication initiation, disturbed ori positioning in } \\
\text { cell poles [95], no segregation defect for } V \text {. cholerae chrI [94] }\end{array}$ \\
\hline \multicolumn{5}{|c|}{ Deinococci } \\
\hline Deinococcus radiodurans & chrI: 3/1/NGTTTcgcGtgaAACN [96] & non-essential & $8 \%-13 \%$ for $\Delta$ parB1, (wt $>1 \%)[96]$ & Reduced growth rate for $\Delta$ parB1 [96] \\
\hline Thermus thermophilus & 1/1/TGTTTCCCGTGAAACA [97] & non-essential & $3 \%$ for $\triangle \operatorname{par} A B(\mathrm{wt} 1.2 \%)[97]$ & No apparent growth defects for $\triangle \operatorname{par} A B[97,98]$ \\
\hline
\end{tabular}


Sequence analysis revealed that the vast majority of the ParA homologs encoded in the chromosomes of Gram-negative and Gram-positive bacteria, as well as Archaea, cluster in a subgroup, distinct from the groups of plasmidic Class Ia ParAs [41]. Chromosomal ParAs lack the N-terminal DNA binding domain, present in plasmidic orthologs and required for autoregulation of the cognate par operon $[99,100]$.

Chromosomal ParAs, like their plasmidic counterparts of Class I, are Walker-type ATPases capable of non-specific DNA binding [101,102] and interactions with cognate ParBs [64,103-105]. After ATP binding, chromosomal ParAs associate non-specifically with the nucleoid. ATP hydrolysis stimulated by interactions with ParB bound to parSs triggers dynamic re-locations of the oriC domains. Several models have been offered to explain the molecular mechanisms used by the ParAs of Class I to move the ParB-parS complex towards the poles, including "pulling" [42,103,106-108], "diffusion-ratchet", and "DNA-relay" [109-111] and these mechanisms are still being discussed (for a review, see [15,112,113]).

Eubacterial chromosomal ParBs (but not archaeal), and plasmid encoded Class Ia partition proteins [41], belong to the ParB family. Chromosomal ParBs cluster together and show a much higher conservation in their clade than more divergent plasmidic ParBs. Despite their apparent diversity, all Class Ia ParBs share a similar domain and functional organization (Figure 2a). The central DNA binding domain (DBD) with an extended HTH motif is connected by flexible linkers, with the N-terminal oligomerization and ParA binding domain (NTD) containing the highly conserved arginine patch, GERRxRA [114-117] (reviewed in [118]), and the C-terminal dimerization domain (CTD) encompassing a leucine zipper $[64,116,119]$. Additionally, in some systems, CTD may be involved in nonspecific DNA interactions (e.g., B. subtilis ParB homolog, designated Spo0J) [119-121].

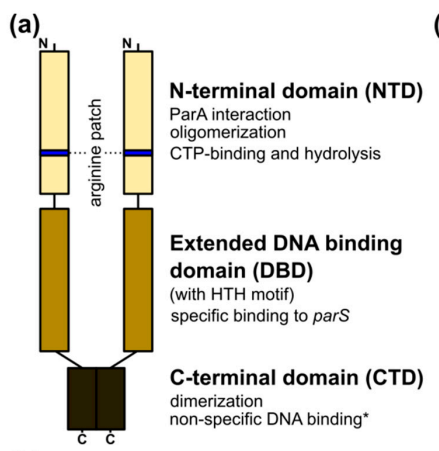

(b)

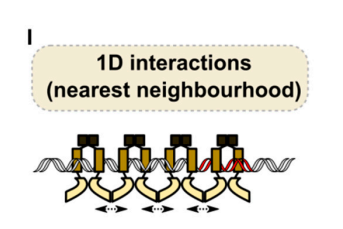

(c)
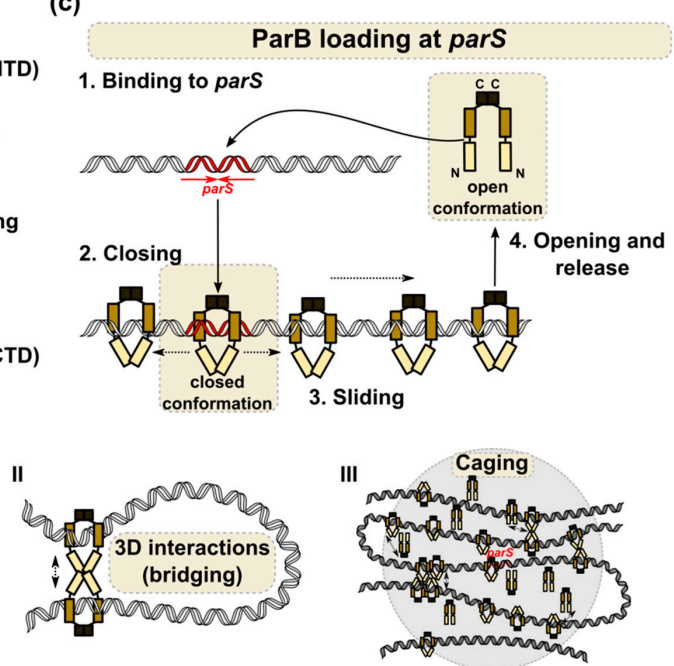

Figure 2. ParB complex assembly at parS. (a) Schematic representation of chromosomally encoded ParB protein (dimer) with the indicated functions of individual domains. *- only confirmed for B. subtilis Spo0J. (b) Models of the ParB-ParB interactions involved in formation of the ParB nucleoprotein complexes around parS. (I) Adjacent ParB dimers may interact with each other to form 1D filaments around parS. (II) Interactions between ParB dimers associated with distal DNA fragments may lead to DNA bridging and looping. (III) ParB self-interactions provide a scaffold (cage), attracting and trapping additional ParB molecules. (c) A model illustrating ParB loading at parS and sliding [122]. Free CTP-ParB exists as a dimer in an open conformation. Binding to parS induces conformational changes involving the N-terminal ParB domains and the formation of "closed" ring-shaped molecules. Steric hindrance between HTH motifs interacting with parS in such a closed conformation may prompt the release of ParB rings from parS via their sliding on adjacent DNA and the loading of new ParB dimers at parS. Finally, switching from a closed to open conformation by an unknown mechanism (possibly involving CTP hydrolysis) may lead to ParB's dissociation from the DNA. The parS sites are indicated in red. 


\section{The Structure of the ParB-parS Complex}

Similarly to their plasmidic orthologs [123-126], chromosomal ParBs have a very unusual feature: after binding to parS as dimers, they spread on adjacent DNA [64,68]. It was shown that ParBs defective in spreading were impaired in partition $[68,114,127]$.

ParB nucleation around the parS sequence correlates with the formation of ParB foci in fluorescence microscopy analyses $[76,92,97,117,127-131]$ or the presence of wide peaks (up to $50 \mathrm{kbp}$ ), encompassing parS in chromatin immunoprecipitation analyses (ChIP-seq or ChIP-microarray), indicating the incorporation of parS proximal DNA in the ParB complex [68,71,72,79,80,89,90,129,132].

A combination of biochemical, structural, and computational approaches can shed light on the possible architecture of the ParB-parS nucleoprotein complex (reviewed in [118]). Nevertheless, no common assembly mechanism has been proposed, thus suggesting dynamic and heterogeneous interactions between ParB molecules within the complex (Figure 2b) [116,122,133,134]. It is widely acknowledged that ParB loading on parS is a prerequisite for the conformational changes that prime ParB for nucleation [135-137]. The ability of ParBs to build large nucleoprotein complexes may be a result of lateral ParB interactions (1D) and bridging interactions (3D) between ParB molecules located at distant DNA segments $[117,134]$, clustering or building a ParB cage around parS by weak but dynamic interactions between protein dimers and DNA $[129,138,139]$. The ParB interactions around parS result in significant DNA compaction via loop formation. Interestingly, non-specific DNA binding also seems to be an important factor in DNA bridging and condensation, at least in some systems [120,121]. All models postulate that multiple ParB-ParB interaction interfaces must be involved in the assembly of higher-order complexes. Structural studies have indeed demonstrated the flexibility of ParB molecules, the ability to bridge different parS sequences, as well as various cross-monomer interactions $[115,116,122,133]$. Notably, the majority of mutational analyses show that the conserved arginine patch residues are required for ParB spreading and DNA partition, thereby indicating the crucial role of this motif in ParB functions $[68,114,127]$.

Mechanistic insight into the loading of B. subtilis Spo0J on parS and the role of the conserved arginine patch was recently provided [122]. Spo0J was shown to hydrolyze cytidine triphosphate (CTP) with the catalytic center encompassing the arginine patch GERRFRA (nucleotide binding residues in bold). In the presence of parS, an open form of the CTP-bound Spo0J dimer favors cooperative CTP binding and closes into a ring-shaped ParB clamp on parS (Figure 2c). The steric hindrance between parS bound $\mathrm{HTH}$ motifs was suggested to promote the detachment of the ParB dimers in a closed conformation from parS, as well as sliding away (spreading). CTP hydrolysis is not required for loading but might instead assist ParB recycling and control ParB spreading, as shown in vitro for C. crescentus ParB [140]. Spreading may also be restricted by road blocks formed by NAPs [122,140]. The role of CTP binding and hydrolysis in ParB-driven partition complex formation was also shown for M. xanthus ParB [141]. Interestingly, in a recent study, Jalal and co-workers demonstrated that ParBs from various bacterial species show variation in their intrinsic capabilities for spreading and that the determinant of this variability maps to the N-terminal domain (NTD) [133]. The study used ChIP-seq to analyze ParB spreading in a heterologous host, so the results may not recapitulate all the determinants affecting the extent of spreading in its original host (like DNA supercoiling, involvement of other proteins). Nevertheless, this demonstrates that the NTD domain might evolve to regulate ParB's association with DNA. 


\section{ParB Binding to Half-parS: A Novel Aspect of ParB-DNA Interactions?}

A recent ChIP-seq analysis of ParB binding in P. aeruginosa added a new dimension to ParB-chromosome interactions [90]. In addition to the ParB-enrichment at parSs [64,91] hundreds of additional sites containing a half-parS motif (mainly GTTCCAC or GTTTCAC) were also shown to be occupied by P. aeruginosa ParB [90]. While ParB binding to four parSs proximal to oriC resulted in a $50 \mathrm{kbp}$ peak, the width of the ParB peaks around the half-parS sites did not exceed $0.6 \mathrm{kbp}$, even under an abundance of ParB, suggesting a distinct mode of interactions.

Interestingly, our analysis of available ChIP-seq data (including the 17 chromosomal ParBs from various species produced in E. coli [142] and tested for DNA binding in this heterologous host, as well as two ParBs from $V$. cholerae and Corynebacterium glutamicum tested in their native hosts) showed that binding to parS half-sites GTTCCAC and GTTTCAC is not a unique feature of P. aeruginosa ParB (Figure 3a,b). ParB of P. aeruginosa and five other ParBs clearly bind to these heptanucleotides even in a heterologous host. Four ParBs show slightly weaker binding, whereas among the remaining nine including B. subtilis, S. coelicolor, V. cholerae, and C. glutamicum, no binding to the selected motifs can be observed. It is feasible that the presence of hundreds of specific ParB-DNA binding sites in the genome enables an additional role of this protein in the modulation of chromosome topology, possibly through the interactions of ParB bound to the half-parS with the ParB complex assembled at parSs, or through bridging distant DNA segments (Figure 3c). These interactions may play a role in local or global DNA condensation in a species-dependent manner. 
(a)

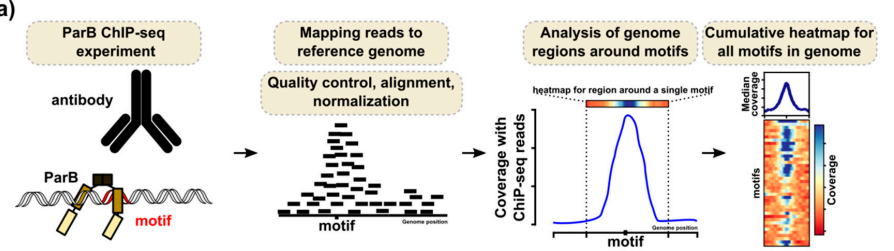

(b)

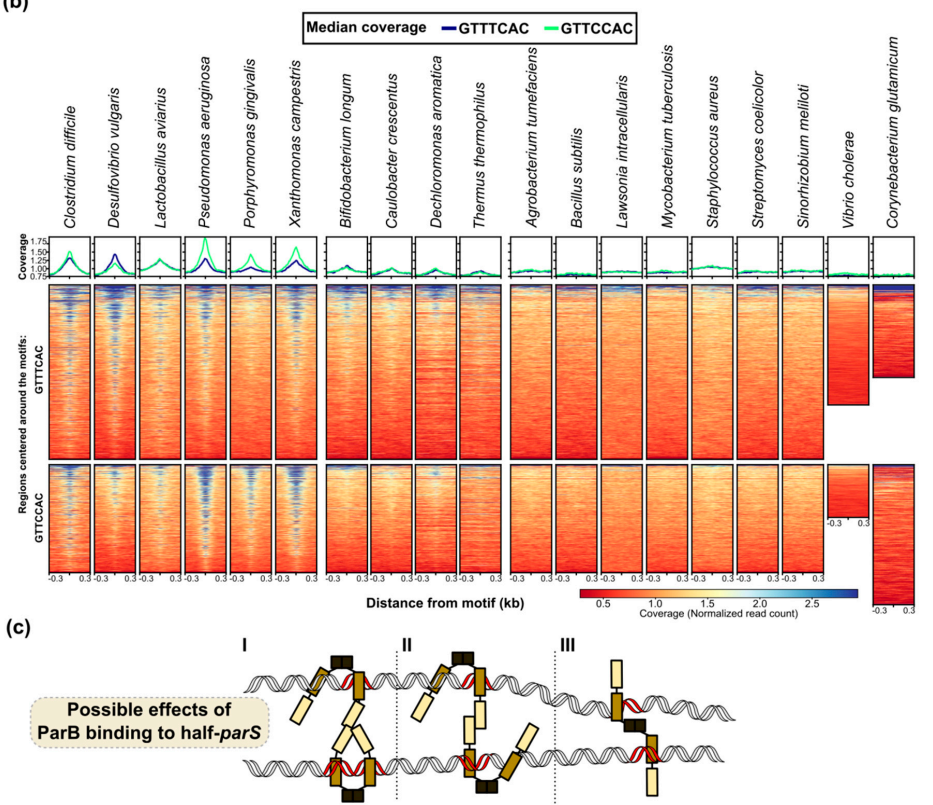

Figure 3. Interactions of ParBs with half-parS sites. (a) Outline of the analysis of ParB binding to half-parS using the available ParB ChIP-seq data. (b) The binding of ParB proteins from various bacterial species to half-parSs assessed by the enrichment of half-parS (GTTCCAC and GTTTCAC) containing genomic DNA fragments in the ChIP samples. Heatmaps represent the read coverage for the ParB ChIP samples, calculated for each nucleotide of a $\pm 300 \mathrm{bp}$ region around all the indicated motifs in the corresponding reference genomes. Plots represent median coverage. A central increase of the coverage indicates enrichment of the DNA containing motif during chromatin immunoprecipitation for the corresponding ParB protein; hence, ParB binds to these sequences. The ChIP-seq data for 17 ParBs from different species produced in E. coli [Gene Expression Omnibus GSE129285 [142]], V. cholerae ParB1 [GSM3161909, GSM3161911 [129]], and C. glutamicum ParB [SRX5581454, SRX5581458, SRX5581460 [72]] were included in the analysis. Raw data were downloaded from the sequence read archive (SRA) and quality-controlled using fastp [143]. Reads were mapped to the reference genomes of E. coli K-12 substr. MG1655 (U00096.3), V. cholerae O1 biovar El Tor str. N16961 (only chrI, NC_002505.1), and C. glutamicum ATCC 13032 (BX927147), respectively, using Bowtie [144] with the -sensitive-local option. Samtools was used to exclude duplicate reads and sort the .bam files [145]. Coverage (.bigwig) files were generated with bamCoverage [146], using the -normalizeUsing RPGC option, without binning and smoothing. Half-parS motifs (GTTCCAC and GTTTCAC) were identified in the corresponding genomes using fuzznuc (Emboss 6.6.0). Heatmap displaying coverage with reads in the ParB ChIP data around the identified motifs were generated using plotHeatmap from deepTools [146]. Each line in the heatmap represents the normalized read counts for each nucleotide of a $\pm 300 \mathrm{bp}$ region around one motif, sorted in the descending order of the mean coverage value and colored according to scale. The median coverage score for the two sets of motifs is presented on plots above the heatmap. For $V$. cholerae and C. glutamicum, the data from the biological replicates were averaged. (c) Hypothetical model engaging the half-parS sites in DNA structuring. I-The ParB complex loaded at parS interacts with an "open" dimeric ParB bound to a half-parS site. II-Interactions between two ParB dimers bound to separate half-parSs. III-Both monomers in a ParB dimer interact with separate half-parSs. All scenarios result in the formation of DNA bridges. In this model, we assume that the binding of ParB to half-parS involves the HTH in the central domain. 


\section{The Role of ParBs in DNA Topology}

The architecture of the origin domain plays an important role in the regulation of replication initiation, global chromosome organization, and DNA segregation $[5,16]$. The conserved feature of the chromosomal ParAB-parS systems is the localization of the par operons and the vast majority of parS sites within the so-called ori domain, defined as $20 \%$ of the chromosome around oriC $[58,59]$, suggesting a functional relation. Among all studied bacteria with complete ParAB-parS systems, ParB homologs perfectly mark and position the oriC regions within the cell, and their absence impairs proper oriC localization during the cell cycle $[68,71,72,76,82,88,92]$. The majority of bacterial species utilizing ParAB-parS for DNA segregation contain more than one parS sequence close to oriC (Table 1). Nevertheless, a single par $S$ site in the vicinity of oriC is enough to secure the proper positioning of oriC in the cell and segregation of the duplicated oriC regions to opposite halves of the cell $[80,89,91]$. Given the bridging ability of ParB, it is feasible that ParB-ParB interactions may gather the parS sites into a single complex. However, microscopy analysis of $C$. glutamicum showed that ParB complexed with distinct parS sites could be observed as individual subclusters [72]. The presence of a multiple parSs adjacent to oriC may therefore secure the proper functioning of segregation machinery and improve its robustness.

In B. subtilis, C. crescentus, C. glutamicum, and S. pneumoniae, the nucleoprotein ParB-parS complexes around oriC serve as platforms recruiting $\mathrm{SMC}-\mathrm{Scp} \mathrm{AB}$ condensin complexes and promoting DNA condensation $[5,6,71,147-149]$. Two SMC subunits interact with the kleisin ScpA associated with the dimer of the accessory protein ScpB [150-152]. Interactions of ParB-parS complexes with SMC complexes direct their binding to DNA in the proximity of oriC $[5,6,148,152]$. Loaded SMC condensin translocates to other parts of the chromosome based on dynamic ATP-dependent transitions between ring-like or open structures [149] and compacts DNA via the loop extrusion mechanism [151,153]. Tethering the two arms of the chromosome together in an ori-ter pattern according to global chromosome organization is dependent on SMC-ScpAB interactions with ParB-parS $[28,72,148,149,154]$.

Among bacteria, two other classes of SMC complexes (MukBEF and MksBEF) have also been described. In E. coli, MukBEF is required for chromosome segregation but does not facilitate inter-arm contacts, only the long-range co-alignment of chromosomal regions belonging to the same replichores $[24,154,155]$. No specific loading factor for MukBEF has been identified, suggesting the random loading of condensin complexes on the DNA. In some organisms, such as P. aeruginosa or C. glutamicum, SMC-ScpAB and MksBEF systems co-exist [72,156,157]. Recent study indicated that in C. glutamicum, MksBEFG, in contrast to SMC complex, does not contribute to chromosomal DNA-folding or long-range chromosome interactions but instead it seems to be involved in replication control of low-copy number plasmids [72]. In M. smegmatis the maintenance of low-copy number plasmids was enhanced by deletion of the eptC gene encoding MukB homologue, suggesting important role of EptC in topology of extrachromosomal elements [157].

S. coelicolor, a representative of Actinobacteria, undergoes drastic changes in chromosome compaction over its complex life cycle. During vegetative growth, elongated hyphal cells are produced with multiple copies of linear uncondensed chromosomes [158]. In sporulating aerial hyphae, unigenomic spores with highly compacted chromosomes are formed. DNA condensation depends on the action of SMC and NAPs specific to sporulation. No indication of ParB-ori complexes recruiting SMC has been reported. Guided by ParA, ParB-bound ori domains were regularly distributed in aerial hyphae before septation in an smc mutant but not in the topA mutant encoding the single topoisomerase I (TopA) in S. coelicolor [158]. Topoisomerases are involved in chromosome topology by maintaining adequate DNA supercoiling, for example, to remove the topological tensions arising during transcription, recombination, and chromosome replication [159]. In linear chromosome of S. coelicolor, one of TopA's functions is related to chromosome segregation during sporulation. The depletion of TopA inhibits the efficient separation of paired ParB complexes, which blocks sporulation and retards growth. Sporulation could be at least partially restored by the deletion of parB. The direct 
interactions between ParB-parS complexes and TopA suggest that ParB recruits TopA to resolve topological constraints created by ParB interactions with ori domains in S. coelicolor [158].

\section{The Role of ParB in the Regulation of Chromosome Replication Initiation}

ParB of B. subtilis was designated Spo0J, and its partner ParA was designated Soj (Suppressor of spoOJ gene), since the first detected phenotype of strain lacking spo0J was a sporulation block, whereas the deletion of both genes restored the process [69]. The role of Spo0J in sporulation results from its indirect involvement in the modulation of DnaA transcriptional regulator activity and its replication initiator activity [160] (Table 2). The latter effect is mediated by Soj, which was shown to act as the negative and positive regulator of DnaA, depending on its nucleotide-bound state [161]. Spo0J stimulates ATP hydrolysis by Soj, as well as the dissociation of Soj dimers. Monomeric Soj interacts with DnaA, disturbing its oligomerization, which is indispensable for replication initiation [162].

In the multipartite genomes of Deinococcus radiodurans and $V$. cholerae $[95,163]$ the parB deletion leads to an increase of the copy number of the cognate replicon. Unlike B. subtilis, where Spo0J negatively controls DNA replication through modulation of Soj activity, in these bacteria, direct interactions between ParB and DnaA proteins were detected. D. radiodurans ParB1, ParB2, ParB3, encoded by chromosome I, chromosome II, and the megaplasmid, respectively, interact with DnaA and DnaB encoded on chromosome 1 [163]. In the case of V. cholerae, both ParA1 and ParB1 directly interact with the DnaA protein [95]. The molecular mechanisms and significance of these interactions remain unclear. 
Table 2. Interactions of ParBs (or ParB-parS complexes) with protein partners and the methods used for their analysis.

\begin{tabular}{|c|c|c|c|c|}
\hline \multirow[b]{2}{*}{ Species } & \multicolumn{4}{|c|}{ ParBs (or ParB-parS complexes) Protein Partners } \\
\hline & $\begin{array}{l}\text { ParA dependent re-locations } \\
\text { of ParB-parS complexes }\end{array}$ & Chromosome ori domain modelling & $\begin{array}{l}\text { Localization/anchoring } \\
\text { Cell division control }\end{array}$ & $\begin{array}{c}\text { Replication initiation } \\
\text { regulation }\end{array}$ \\
\hline Bacillus subtilis & $\stackrel{+}{+}$ & $\begin{array}{l}\text { SMC; Interplay between SMC and } \\
\text { ParB-parS complexes shown by ChIP-seq, } \\
\text { FM, and mutational analysis (deletion of } \\
\text { parB or parS sites affect SMC foci } \\
\text { formation) }[5,6]\end{array}$ & $\begin{array}{l}\text { DivIVA; Direct interaction confirmed by Co-IP, Spo0J may } \\
\text { participate in switching between vegetative growth and } \\
\text { sporulation [164] }\end{array}$ & $\begin{array}{c}\text { \#DnaA; Spo0J induces NTPase } \\
\text { activity of Soj (ParA), the DnaA } \\
\text { regulator } \\
{[160,161]}\end{array}$ \\
\hline Myxococcus xanthus & ND & & $\begin{array}{l}\text { \#PadC; PadC mediates the binding of ParA to BacNOP } \\
\text { cytoskeletal proteins (BLI); ParB may interact with BacNOP } \\
\text { through a yet unidentified protein (pull-down) }[141,165]\end{array}$ & \\
\hline $\begin{array}{l}\text { Mycobacterium } \\
\text { smegmatis }\end{array}$ & $\stackrel{+}{+}$ & $\begin{array}{l}\text { SMC; Interplay between SMC and } \\
\text { ParB-parS complexes shown by FM and } \\
\text { mutational analysis (deletion of parB } \\
\text { affects SMC foci formation) [75] }\end{array}$ & $\begin{array}{l}\text { \#DivIVA (Wag31); ParA interacts with DivIVA and } \\
\text { mediates nucleoid anchoring at the cell poles, } \\
\text { co-localisation confirmed by the FM of labelled proteins, } \\
\text { interactions proven by BACTH and pull-down }[166,167]\end{array}$ & \\
\hline $\begin{array}{l}\text { Streptococcus } \\
\text { pneumoniae }\end{array}$ & $\begin{array}{l}\text { lack of ParA; CpsD, } \\
\text { Walker-type ATPase, is involved } \\
\text { in ParB-parS movements [168] }\end{array}$ & $\begin{array}{l}\text { SMC; Interplay between SMC and } \\
\text { ParB-parS complexes shown by FM and } \\
\text { mutational analysis (deletion of parB } \\
\text { affects SMC foci formation) [71] }\end{array}$ & $\begin{array}{c}\text { DivIVA; Direct interactions confirmed by Co-IP and } \\
\text { BACTH [169] } \\
\text { RocS; Co-localisation confirmed by FM of labelled proteins, } \\
\text { direct interactions confirmed by Co-IP and MST [170], RocS } \\
\text { and ParB participate in DNA segregation; } \\
\text { CpsD*; Co-localisation confirmed by FM of fusion proteins, } \\
\text { direct interaction (CpsD phosphorylation dependent) } \\
\text { confirmed by Co-IP and MST, CpsD and ParB cooperate in } \\
\text { coordination with DNA segregation, cell division, and } \\
\text { capsule formation [168] }\end{array}$ & \\
\hline $\begin{array}{l}\text { Streptomyces } \\
\text { coelicolor }\end{array}$ & $\stackrel{+}{+}$ & $\begin{array}{l}\text { TopA; Interactions with ParB-parS } \\
\text { complexes proven by pull-down, Co-IP, } \\
\text { ChIP-seq; these interactions may support } \\
\text { chromosome resolution [158] }\end{array}$ & $\begin{array}{l}\text { \#ParJ; ParJ negatively regulates the ParA polymerization } \\
\text { indispensable for chromosome segregation, direct } \\
\text { interaction confirmed by BACTH and SPR [172] } \\
\text { \#Scy; The polarity determinant interacts with ParA, } \\
\text { co-localisation confirmed by FM of labelled proteins, direct } \\
\text { interactions confirmed by BACTH, co-purification and SPR, } \\
\text { ParA and Scy coordinate growth and chromosome } \\
\text { segregation [173] }\end{array}$ & \\
\hline
\end{tabular}


Table 2. Cont.

\begin{tabular}{|c|c|c|c|c|}
\hline \multirow[b]{2}{*}{ Species } & \multicolumn{4}{|c|}{ ParBs (or ParB-parS complexes) Protein Partners } \\
\hline & $\begin{array}{l}\text { ParA dependent re-locations } \\
\text { of ParB-parS complexes }\end{array}$ & Chromosome ori domain modelling & $\begin{array}{l}\text { Localization/anchoring } \\
\text { Cell division control }\end{array}$ & $\begin{array}{l}\text { Replication initiation } \\
\text { regulation }\end{array}$ \\
\hline $\begin{array}{l}\text { Caulobacter } \\
\text { crescentus }\end{array}$ & $\stackrel{+}{+}$ & $\begin{array}{c}\text { SMC; Interplay with ParB-parS } \\
\text { complexes shown by Hi-C, ChIP-seq, and } \\
\text { mutational analysis, ParB dependent } \\
\text { loading also detected on differently } \\
\text { positioned parS sites [151] }\end{array}$ & $\begin{array}{l}\text { PopZ*; Co-localisation confirmed by the FM of labelled } \\
\text { proteins, direct interactions confirmed by Co-IP and SPR, } \\
\text { EMSA (PopZ with ParB-parS complexes), PopZ-ParB-parS } \\
\text { complexes mediate chromosome anchoring to the cell } \\
\text { poles [175] } \\
\text { \#PopZ*; PopZ interacts also with ParA, co-localisation } \\
\text { confirmed by FM of labelled proteins, direct interaction } \\
\text { confirmed by Co-IP and SPR, interactions between PopZ } \\
\text { and ParA mediate chromosome movement towards the } \\
\text { swarmer pole [176] } \\
\text { MipZ* Co-localisation confirmed by the FM of labelled } \\
\text { proteins, direct interactions confirmed by SPR and EMSA } \\
\text { (MipZ with ParB-parS complexes), ParB-MipZ complexes } \\
\text { control Z-ring positioning [177] } \\
\text { \#TipN; The polarity determinant interacts with ParA, direct } \\
\text { interactions proven by FM and SPR, ParA-TipN complexes } \\
\text { anchor ParB-parS (ori domain) to the new cell pole [103,178] }\end{array}$ & \\
\hline $\begin{array}{l}\text { Corynebacterium } \\
\text { glutamicum }\end{array}$ & $\stackrel{+}{+}$ & $\begin{array}{l}\text { SMC; Interplay with ParB-parS } \\
\text { complexes shown by FM, ChIP-seq, } \\
\text { deletion of parB or parSs results in the loss } \\
\text { of SMC loading and foci formation [72] }\end{array}$ & $\begin{array}{l}\text { FtsZ; Direct interactions confirmed by BACTH [73] } \\
\text { PldP*; Direct interactions confirmed by BACTH [73], } \\
\text { putative new cell division control system }\end{array}$ & \\
\hline $\begin{array}{l}\text { Deinococcus } \\
\text { radiodurans }\end{array}$ & $\begin{array}{c}+ \\
{[179]}\end{array}$ & & $\begin{array}{c}\text { MinC; Interactions with ParB1 (chrI), ParB3 (megaplasmid), } \\
\text { and ParB4 (plasmid) confirmed by BACTH [180]; } \\
\text { DivIVA; Interactions with ParB1, ParB2, ParB3, and ParB4 } \\
\text { confirmed by BACTH and Co-IP [181]; } \\
\text { ParB1 interacting with DivIVA may mediate chromosome } \\
\text { anchoring to the cell poles and through interactions with } \\
\text { FtsZ inhibitor MinC may affect the cell division. } \\
\text { Interactions of DivIVA and MinC with ParB2-4 coordinate } \\
\text { the segregation of multipartite genome and cell division. }\end{array}$ & $\begin{array}{l}\text { DnaA, DnaB; interactions with } \\
\text { ParB1(chrI) ParB2 (chrII) and } \\
\text { ParB3 (megaplasmid), } \\
\text { confirmed by BACTH and } \\
\text { Co-IP; these interactions } \\
\text { probably regulate DNA } \\
\text { replication initiation [163] }\end{array}$ \\
\hline
\end{tabular}


Table 2. Cont.

\begin{tabular}{|c|c|c|c|c|}
\hline \multirow[b]{2}{*}{ Species } & \multicolumn{4}{|c|}{ ParBs (or ParB-parS complexes) Protein Partners } \\
\hline & $\begin{array}{l}\text { ParA dependent re-locations } \\
\text { of ParB-parS complexes }\end{array}$ & Chromosome ori domain modelling & $\begin{array}{l}\text { Localization/anchoring } \\
\text { Cell division control }\end{array}$ & $\begin{array}{c}\text { Replication initiation } \\
\text { regulation }\end{array}$ \\
\hline Vibrio cholerae & $\begin{array}{c}+ \\
{[107]}\end{array}$ & & $\begin{array}{l}\text { \#HubP; ParA1 interacts with HubP to mediate nucleoid } \\
\text { anchoring at the cell poles; interactions confirmed by the } \\
\text { FM of fusion proteins and BACTH [182] }\end{array}$ & $\begin{array}{l}\text { DnaA; Interactions with ParB] } \\
\text { confirmed by BACTH, a } \\
\text { proposed role in the regulation } \\
\text { of replication initiation [95] }\end{array}$ \\
\hline $\begin{array}{l}\text { Hyphomonas } \\
\text { neptunium }\end{array}$ & $\begin{array}{c}+ \\
{[83]}\end{array}$ & & $\begin{array}{l}\text { PopZ*; Co-localisation with ParB-parS in the swarmer cells } \\
\text { and in the bud compartments confirmed by the FM of } \\
\text { tagged proteins [ } 83 \text { ] }\end{array}$ & \\
\hline $\begin{array}{l}\text { Rhodobacter } \\
\text { sphaeroides }\end{array}$ & ND & & $\begin{array}{l}\text { MipZ; Co-localization demonstrated by the FM of fusion } \\
\text { proteins; direct interactions confirmed by BACTH; the } \\
\text { ParB-MipZ system supports the Z-ring assembly and its } \\
\text { stability [183] }\end{array}$ & \\
\hline $\begin{array}{l}\text { Magnetospirillum } \\
\text { gryphiswaldense }\end{array}$ & ND & & $\begin{array}{c}\text { MipZ1*; Co-localization demonstrated by the FM of fusion } \\
\text { proteins; direct interactions confirmed by BLI, ParB-MipZ1 } \\
\text { system controls Z-ring positioning; MipZ2* may also } \\
\text { interact with ParB [184] }\end{array}$ & \\
\hline
\end{tabular}

ND: not determined; \#: Indirect interactions mediated by the cognate ParAs; *: ParA-like protein, Walker-type ATPase; FM: Fluorescence microscopy; BACTH: Bacterial two hybrid system; Co-IP: Co-immunoprecipitation; Hi-C: chromosome conformation capture; ChIP-seq: Chromatin immunoprecipitation followed by DNA sequencing; SPR: Surface plasmon resonance; EMSA: Electrophoretic mobility shift assay; MST: Microscale thermophoresis; BLI: Bio-layer interferometry. 


\section{Involvement of ParB in The Nucleoid Occlusion}

Deletion of the spo0J gene from the B. subtilis chromosome results not only in aberrant DNA replication and sporulation but also affects cell division [70]. Elongated cells were detected in populations of strains deprived of Spo0J or both, Spo0J and Soj, but not in the strain lacking only Soj [70]. In B. subtilis, two systems controlling cell division were described (for a review, see [185]). The Min system hampers the formation of the cytokinetic Z-ring composed of tubulin like FtsZ protein close to the cell poles [186]. The nucleoid occlusion (NO) system prevents premature Z-ring formation over the nucleoid until most of the chromosomal DNA has been segregated. Spo0J together with its paralog, Noc [187-189], block premature Z-ring assembly, preventing chromosome guillotining in the dividing cells. The deletion of either noc (initially named yyaA) or spo0J results in aberrant cell division, and the deletion of both noc and spo0J has a synergistic effect, potentiating the aberrations [190].

\section{The Interactions of ParB with Topological Determinants during Cell Division}

Another aspect of ParB's involvement in the cell division process is its interplay with proteins located at the cell poles, such as DivIVA in B. subtilis [164] (Table 2). DivIVA is a highly conserved component of the Min system (equivalent to the E. coli MinE protein in the MinCDE system) in a wide range of Gram-positive bacteria (for a review, see [191]). The biological functions and significance of DivIVA vary among different bacterial species. However, the primary role of DivIVA (as one of the Min proteins) seems to be the proper positioning of the cell division site. Since Spo0J-DivIVA interactions are observed in B. subtilis only during the early stages of sporulation when DivIVA supports Spo0J-parS guided orientation of the chromosome and its polar attachment, it is postulated that DivIVA is also involved in the molecular switch between vegetative cell division and spore formation [164].

Interactions between DivIVA and ParB were also detected in the non-sporulating bacteria S. pneumoniae [169] and D. radiodurans [180,181]. In the latter, DivIVA interacts with various ParBs encoded by the multipartite genome, with ParB1 (chrI), ParB2 (chrII), and ParB3 and ParB4 from the megaplasmid and plasmid, respectively. In the case of D. radiodurans, ParB1, ParB3, and ParB4 also interact with another Min protein-MinC that functions as an FtsZ polymerization inhibitor [180].

It should be noted that, in some cases, ParB may be indirectly engaged in ori domain anchoring (Table 2). In Mycobacterium smegmatis, ParA, instead of ParB, interacts directly with DivIVA [166]. In S. coelicolor, both ParA and ParB are involved in localization of the segrosome in hyphae [171]. However, only ParA interacts with so-called 'polarisome' or tip-organizing complex (TIPOC), which includes DivIVA and the coiled-coil protein, Scy, and anchors the segrosome at the tips. Whereas ParA and Scy direct interactions have been confirmed [173], there is no evidence for ParA (or ParB) and DivIVA interactions in S. coelicolor [191]. In C. crescentus, ParA mediates the ParB-DNA complex's positioning at the new cell pole via interactions with the TipN protein [178]. In V. cholerae, ParB1-oriC1 complex is targeted to the cell pole via interactions between the polar protein HubP and ParA1 [182].

In $\alpha$-proteobacteria, lacking Min and NO systems, ParB interacts with PopZ, polar organizing protein Z (DivIVA functional equivalent), and MipZ, the mid-cell positioning of the FtsZ protein $[175,177,192]$. PopZ is a key component in the regulation and coordination of chromosome replication and partitioning in C. crescentus, a bacterium with a dimorphic lifestyle (for a review, see [193]). In this organism, cell division leads to the formation of a mobile swarmer cell and a non-mobile stalker cell. However, only the latter is able to duplicate [194]. The ori domain of the longitudinally oriented chromosome is anchored to the stalked pole by direct interactions between ParB-parS and PopZ [175]. Immediately after DNA replication initiation, one of the duplicated ori domains begins translocation towards the opposite pole, assisted by the ParAB-parS system. Simultaneously, the mono-polar localization of PopZ is switched to the bi-polar localization, and the transferred ParB-parS complex (ori domain) is attached to the cell membrane via the PopZ protein complex at the swarmer pole [192]. At this stage of the chromosome segregation also ParA directly interacts with PopZ protein [176].

In the marine alpha-proteobacterium, Hyphomonas neptunium, which proliferates by bud formation at the tip of a stalk-like cellular compartment, a unique two-step chromosome segregation process 
occurs [83]. Initially, two newly replicated ori domains are segregated to opposite poles of the mother cell via a ParAB-parS dependent mechanism. When the bulk of the chromosome has been replicated, the cell produces a bud (swarmer cell), and a next segregation step largely independent of replication begins. This step involves the translocation of a stalk-proximal ParB-origin region through the stalk to the bud compartment by an unknown mechanism. PopZ's homolog from H. neptunium associates with the ParB-parS complex in swarmer cells and in the bud compartment at a later stage of the cell cycle, possibly acting as a tether for the ori domain at the new bud pole [83].

DNA segregation and the PopZ mediated attachment of ParB-parS complexes at the cell poles are critical for the appropriate positioning and formation of the cytokinetic Z-ring. In C. crescentus, ParB is also involved in the formation of a bi-polar gradient of MipZ, a polymerization inhibitor of the FtsZ protein, and both ParB and MipZ are indispensable [177]. ParB stimulates the formation of MipZ dimers, negatively affecting the polymerization of FtsZ and hence Z-ring formation [177]. MipZ dimers are also able to bind DNA in a non-specific manner [195]. This binding stimulates MipZ ATPase activity and promotes dimer dissociation, which results in a release of MipZ monomers from the DNA [196]. In C. crescentus, MipZ forms a bipolar comet-like gradient with the highest concentration of MipZ in the cell poles and the lowest concentration in the midcell before division. This distribution of MipZ depends on the ParB-parS complex movement from the stalked pole to the swarmer pole and promotes Z-ring positioning at the midcell. In another representative of $\alpha$-proteobacteria, Rhodobacter sphaeroides, the bipolar comet-like gradient of MipZ was not detected [183]. Detailed studies revealed that R. sphaeroides MipZ, similarly to C. crescentus MipZ, interacts with ParB as a monomer and inhibits FtsZ as a dimer. However, in this organism, MipZ dimers are never present at the cell poles but form a ring-like structure at the midcell, facilitating Z-ring assembly and stability rather than Z-ring positioning (as was postulated for C. crescentus) [183].

Finally, a functional analysis of two MipZ-like proteins encoded by mipZ1 and mipZ2 in Magnetospirillum gryphiswaldense revealed that MipZ1 is crucial for proper cell division, and MipZ2 has only a minor effect on this process [184]. MipZ1 interacts with ParB and forms a bipolar comet-like gradient akin to MipZ of C. crescentus, while MipZ2 localizes to the cell division site similar to the MipZ of R. sphaeroides [184].

The role of ParB in cell division was also postulated in C. glutamicum [73]. Similarly to C. crescentus, C. glutamicum lacks Min and NO systems. C. glutamicum ParB interacts not only with ParA but also with the ParA homologue, the PldP protein (with a $62 \%$ sequence similarity). Analysis of the pldP mutant showed significant defects in the cell division, comparable to E. coli and B. subtilis mutants in min genes [73]. In vitro, ParB interacts not only with PldP but also with the FtsZ protein. It is not clear at which stage of the cell cycle the crosstalk between DNA segregation and cell division takes place. A fluorescently labelled PldP protein can be detected as visible foci near the cell division site, but diffused PldP is also present in the cytoplasm [73].

\section{ParB's Role in Capsule Formation in S. pneumoniae}

In S. pneumoniae, ParB interacts with DivIVA during cell division. It has also been shown that ParB participates in specific crosstalk between DNA segregation, cell division, and capsule formation in this organism [168,170]. S. pneumoniae's incomplete Par(A)B-parS system consists of four parS sites close to oriC, as well as an orphan parB gene [197]. The deletion of parB impairs chromosome segregation but only in a minor way and has no influence on bacterial growth [71]. Recent reports have shed light on the role of $S$. pneumoniae ParB, showing that it cooperates with two proteins, CpsD and RocS [168,170]. Capsular polysaccharide protein D (CpsD), a ParA-like ATPase, is a component of a protein complex involved in the synthesis and export of capsular polysaccharide. Together with the membrane associated $\mathrm{CpsC}$, it forms a tyrosine autokinase. Autophosphorylated CpsD stimulates ParB-parS binding and promotes chromosome segregation, as well as cell division and capsule formation. Non phosphorylated CpsD delays ParB-parS translocation to the cell equator and negatively affects cell division [168]. Another ParB partner, RocS (Regulator of chromosome 
Segregation), was initially identified as a CpsD partner in the control of cell division [170]. RocS is a non-specific DNA binding protein, with a N-terminal MarR-like HTH motif and a C-terminal MinD-like cell membrane binding helix [170]. RocS and ParB seem to have partially overlapping functions in S. pneumoniae, and a double deletion of rocS and parB is lethal. However, the lack of RocS has a more deleterious effect on DNA segregation than ParB deficiency alone [170]. In contrast to ParB, RocS is not involved in capsule formation but is directly involved in cell division control through CpsD. Thus, in S. pneumoniae, this unique system, involving ParB, RocS, and CpsD (CpsC) proteins, coordinates and secures DNA segregation, cell division, but also capsule formation, which is critical for bacterial virulence [170].

\section{Impact of ParBs on Gene Expression}

The autoregulation of partition operon expression is a common feature of plasmidic systems [41]. However, in the Class Ia type of par loci, ParA acts as a repressor, binding in the promoter region of the par $A B$ operon, whereas ParB usually works as a co-repressor $[41,99,100]$. The known examples of plasmidic ParBs of Class Ia playing the role of the global transcriptional regulators include the KorBs of IncP-1 plasmids [126,198,199] and related KorB of IncU plasmids [200].

For chromosomal ParB proteins, artificial insertion of the parS sequence upstream of the repA promoter in the test plasmid was used to demonstrate the negative effect of P. aeruginosa ParB binding to parS on expression of the adjacent genes [64]. The flexibility of ParBs in self-interactions via the use of NTDs and CTDs, specific and unspecific interactions with DNA and interactions with multiple partners (Figure 4) may facilitate the formation of the expanded ParBs network, potentially influencing gene expression.

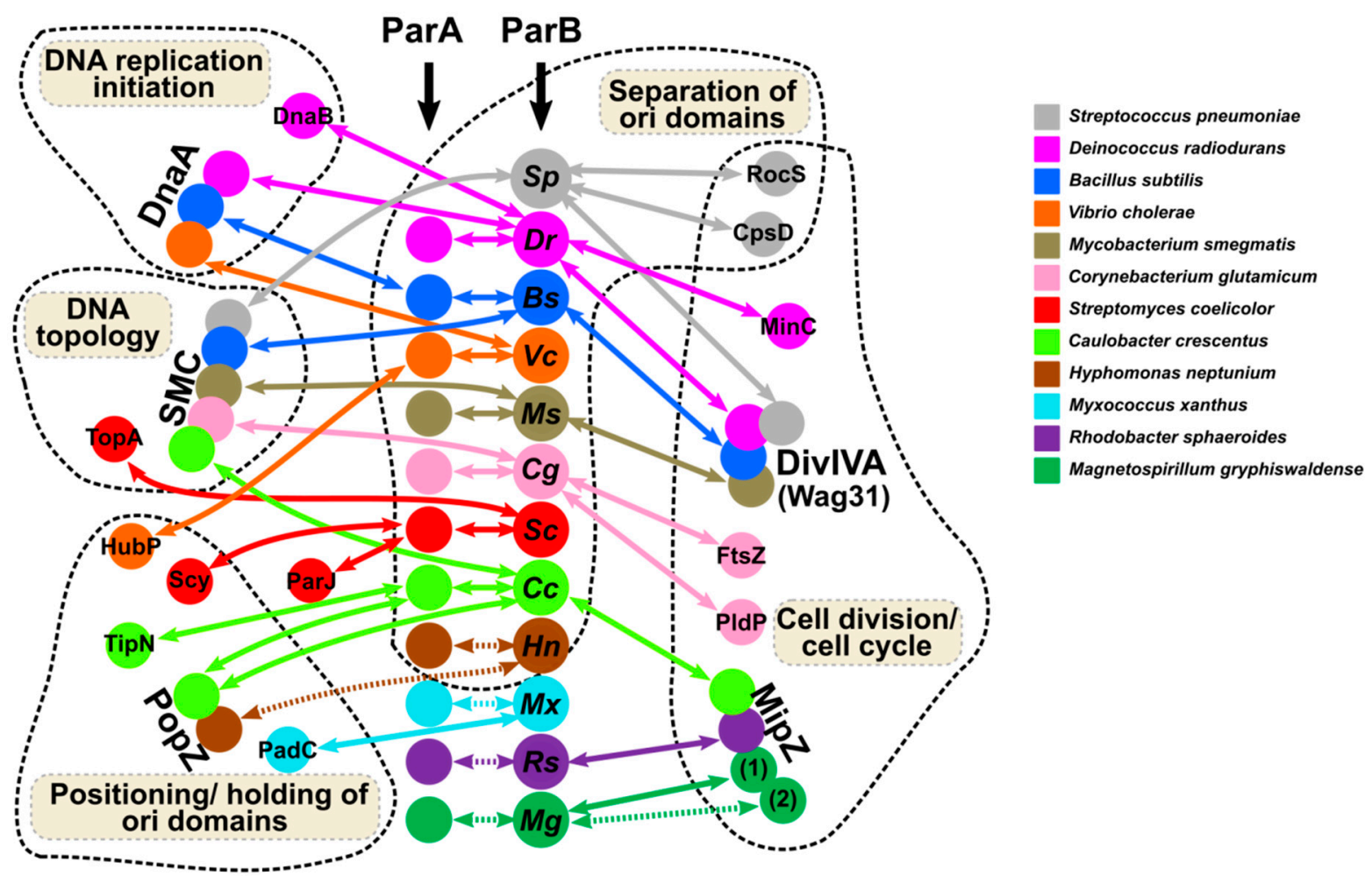

Figure 4. Network of ParBs interactions with ParAs and other partners coordinating chromosome segregation with various cellular functions in the analyzed bacterial species. The dashed arrows indicate interactions not yet confirmed experimentally.

In recent years, the relation between ParB binding to chromosomal DNA and the expression of loci close to the corresponding parS sites has been systematically investigated using a combination 
of ChIP methods and genome-wide transcriptomic approaches. In B. subtilis, Spo0J was observed to bind to and around 10 parS sequences. However, a lack of Spo0J did not affect the expression of genes adjacent to these sites [68]. Spo0J deficiency resulted in an elevated expression of only the fruR gene (encoding a putative transcriptional regulator), whereas the mRNA levels of nine other genes, among them, the sporulation genes spoIIGA, $\cot E, \cot G, \operatorname{spoIIAA}$, and $\operatorname{sig} E$, were decreased [68]. This negative effect of sporulation gene regulation can be explained by the influence of Spo0J deficiency on the Soj mediated activation of the Sda replication check point [160].

The influence of ParB on gene expression was also studied in $V$. cholerae, a bacterium with two chromosomes, each encoding their own partitioning system (parABS1 and parABS2). Chromatin precipitation combined with the microarray technique (ChIP-chip) confirmed that ParB1 bound to three parS motifs and spread for $16 \mathrm{kbp}$ [132]. The transcriptomic analysis of the $\triangle$ parB1 mutant revealed a changed expression of only three genes in the region occupied by ParB and several more outside of this region. Cloning promoters of these three genes upstream of the promoter-less lacZ on the plasmid eliminated the regulatory effect of ParB1, indicating that genetic localization and/or DNA topology play a role in the regulation of these promoters by ParB1. The role of ParB1 in controlling gene expression outside of the highly ParB-enriched zone was postulated to be indirect through interactions with other regulatory proteins [132].

A similar transcriptional analysis in S. pneumoniae showed that a lack of ParB affected the expression of eight genes. However, none of these genes were located in proximity to the four parS sequences identified in this organism [130]. Significantly, ParB deficiency resulted in a modest increase in the expression of the com $C D E$ operon involved in the regulation of competence and located 5 kbp away from parS $\left(-1.6^{\circ}\right)$ [130]. Mutating parS $\left(-1.6^{\circ}\right)$ to block ParB binding was sufficient to induce comCDE expression, suggesting that a ParB complex formed at a single par $S$ may influence the expression of promoters at a distance. Attempts to recapitulate this effect with the insertion of a strong synthetic promoter in the region failed, suggesting a highly selective mechanism by which the ParB complex at parS $\left(-1.6^{\circ}\right)$ influences com $C D E$ expression and, as a result, the development of the competence cascade [130].

The genome wide transcriptome analyses presented above indicate that ParB deficiency results in minor changes in the cell transcriptomes of the tested species. However, the analysis of ParB deficient $P$. aeruginosa cells from exponentially growing cultures in rich medium showed expression changes for 1166 genes, which is around 20\% of all loci [201]. Additionally, global changes in the transcriptome were also observed in ParA deficient cells; 697 genes showed altered expression in the $\Delta$ parA mutant, and $77 \%$ of them overlapped with the gene pool affected by ParB deficiency [201]. This overlap is not surprising, as previous data indicated that ParA deficiency in this organism promotes ParB degradation [92]. The wide range of changes in the transcriptomes of par mutants reflect a wide spectrum of various growth defects. The lack of par A or parB in P. aeruginosa leads up to a 1000-fold increase in the number of cells with defects in their chromosome segregation, extended division times, longer cells, altered colony morphology, and impaired swimming and swarming motility [92,202]. We cannot exclude that observed changes in the expression of some genes result from the aberrations in ParB and/or ParA dependent processes like DNA segregation although anucleate cells constitute only $2 \%-4 \%$ of population under analyzed conditions. Significantly, not only depletion, but also mild overproduction of ParB protein lead to global transcriptome changes in P. aeruginosa [203].

$P$. aeruginosa ParB binds to a cluster of four parS sequences (parS1-4) in the vicinity of oriC to form a large nucleoprotein complex, and the binding to one of these sites is required and sufficient for proper chromosome segregation [89-91]. The analysis of the mRNA levels of genes adjacent to parS1-4 showed that direct ParB interactions with intergenic parS3 and parS4 motifs located upstream of PA0011 and PA0013, respectively, repressed their expression, while the expression of other genes in the analysed region was unchanged in the parB and parS1-4 deficient cells [203]. Concomitantly, a mild overproduction of ParB led to a more pronounced transcriptional silencing of the majority of genes in the vicinity of the parS1-4 cluster. This observation suggests that the size, composition, or 
stability of the ParB nucleoprotein complex may dictate the effect on gene expression [203]. Strikingly, our recent study demonstrated that in P. aeruginosa, ParB was bound to numerous sites containing a heptanucleotide half-parS. However, the binding to half-parS sites may not directly account for the transcriptome changes ParB exerts. Only 15\% of ParB enriched half-parS sites localizes in intergenic regions with putative transcriptional initiation signals [90]. Binding of P. aeruginosa ParB to hundreds of specific DNA motifs may have a great impact on chromosome topology (Figure 3c). ParBs from several other bacterial species also bind to GTTCCAC and GTTTCAC sequences (Figure 3b), indicating that $P$. aeruginosa ParB is not unique in this mode of interaction. The significance of these interactions in cell processes (including gene expression regulation) requires further studies.

\section{Conclusions and Future Perspectives}

ParAB-parS systems are encoded close to oriCs in the chromosomes of most bacterial species [41,59]. The primary role of ParAB-parS systems is undoubtedly the segregation of newly replicated DNA. ParB binding to parSs in the proximity of oriC, structuring ori domains, directing their motion with the help of the ParA partner, and the anchoring of ori domains at the defined locations are vital for accurate segregation of the genomes. With a few exceptions (Table 1), this system is not essential for cell survival but rather an accessory to hypothetical but attractively more universal entropy-driven DNA segregation machinery [204,205]. In some species, like T. thermophilus, the ParAB-parS system seems not to be involved at all in DNA segregation [98]. New sophisticated molecular biology methods revealed the details of chromosome segregation, providing insight into the formation and structure of the ParB nucleoprotein complex, as well as the mechanisms responsible for its relocation to specific cell positions. Nevertheless, the picture of this process is far from complete. The diversity of the Par partners (Table 2 and Figure 4) and the species-specific requirements for cell cycle proceedings still lead to new exciting discoveries $[83,206]$.

ParB proteins seem to be engaged in crosstalk between DNA segregation, DNA replication, cell growth, and division. The synchrony of these processes in non-compartmentalized cells emphasizes the significance of such crosstalk (reviewed in [193]). The ParBs domain's composition and structural flexibility facilitates various modes of interactions with specific (parS and half-parS sites) and non-specific DNA and points to multiple interfaces for self-interactions and cooperation with different protein partners. The involvement of ParBs in a variety of cell functions directly through direct interactions with vital cell components or indirectly using their primary partners, ParAs, is summarized in Figure 4. To achieve that, they target similar main players in different species (DnaA, SMC, DivIVA, MipZ) or adapt to species-specific factors playing the same function, such as a polar positioning.

The role of ParB as a transcriptional regulator has been shown in a limited number of species and for a limited number of genes, not necessarily located close to the parS sites. The most intriguing is the biological significance of ParB binding to half-parSs observed in some species, despite the common occurrence of these motifs in the genomes. In P. aeruginosa and a few other species ParB binds to hundreds of half-parS sites (Figure 3b). These interactions may induce topological constraints leading to the observed ParB role as a global transcriptional regulator in P. aeruginosa [201].

One of the most poorly understood aspects of ParBs functioning is the nature of molecular switches that control the level and activity/conformation of ParBs. Par proteins are not as abundant as histone-like proteins [68,92]. The level of Par proteins, possibly influencing their activities, could be controlled by different mechanisms. The regulation of parB and parA expression has only been partially studied in a limited number of bacteria species (e.g., [84,132,207,208]). Alternatively, the levels of Par proteins could be modulated by cell proteases, e.g. depending on the phase of growth [92].

The observation that ParB loading at parS and sliding on DNA requires CTP binding [122,140,141], a key metabolite in DNA and phospholipids synthesis, adds CTP to the players possibly regulating the ParB-DNA interactions. The motif containing amino acid residues responsible for CTP binding and ParB CTPase activity is one of the most conserved elements within the ParB protein sequences [122,141]. This suggests that CTP binding and hydrolysis may be crucial for proper ParB functioning, not only in 
the abovementioned B. subtilis [122], M. xanthus [141] and C. crescentus [133], but also in other bacteria encoding ParAB-parS systems.

An increasing number of important bacterial proteins have been shown to undergo post-translational modifications (PTMs), such as phosphorylation or acetylation [209-211]. M. tuberculosis ParB is phosphorylated by Serine/Threonine Protein Kinases (STPKs), including PknB, a key component of the signal transduction pathway that regulates, for example, cell division and the survival of the pathogen in the host $[212,213]$. This PTM negatively affects ParB's DNA binding properties in vitro, as well as ParB interactions with the cognate ParA protein partner. The regulation of ParB activity by direct phosphorylation or acetylation is not the only way to affect its activity, as its partners' activity may be dependent on PTM. For example, the functions of S. pneumoniae ParB depend on interactions with the membrane bound $\mathrm{CpsC} / \mathrm{D}$ tyrosine auto-kinase [168]. We also cannot exclude the possibility that $\mathrm{CpsC/D}$ phosphorylates S. pneumoniae ParB, like in the case of M. tuberculosis auto-kinases from the STPK family [212].

The biological roles of chromosomally encoded ParBs and the molecular basis of their functions are more complex than was previously thought. It is clear that despite the significant conservation of chromosomal ParAB-parS systems, these systems evolved independently in different bacterial species. ParBs seem to be excellent models for studying many aspects of bacterial molecular biology and genome evolution.

Funding: This work was financed by the Polish National Science Centre, grant no 2018/29/B/NZ2/01745 awarded to GJB.

Conflicts of Interest: The authors declare no conflict of interest. The funders had no role in the design of the study; in the collection, analyses, or interpretation of data; in the writing of the manuscript, or in the decision to publish the results.

\section{References}

1. Dame, R.T.; Rashid, F.-Z.M.; Grainger, D.C. Chromosome organization in bacteria: Mechanistic insights into genome structure and function. Nat. Rev. Genet. 2019. [CrossRef] [PubMed]

2. Badrinarayanan, A.; Le, T.B.; Laub, M.T. Bacterial chromosome organization and segregation. Annu. Rev. Cell Dev. Biol. 2015, 31, 171-199. [CrossRef] [PubMed]

3. Dorman, C.J. Genome architecture and global gene regulation in bacteria: Making progress towards a unified model? Nat. Rev. Microbiol. 2013, 11, 349-355. [CrossRef] [PubMed]

4. Dame, R.T.; Tark-Dame, M. Bacterial chromatin: Converging views at different scales. Curr. Opin. Cell Biol. 2016, 40, 60-65. [CrossRef] [PubMed]

5. Gruber, S.; Errington, J. Recruitment of condensin to replication origin regions by ParB/Spo0J promotes chromosome segregation in B. subtilis. Cell 2009, 137, 685-696. [CrossRef] [PubMed]

6. Sullivan, N.L.; Marquis, K.A.; Rudner, D.Z. Recruitment of SMC by ParB-parS organizes the origin region and promotes efficient chromosome segregation. Cell 2009, 137, 697-707. [CrossRef]

7. Schwartz, M.A.; Shapiro, L. An SMC ATPase mutant disrupts chromosome segregation in Caulobacter. Mol. Microbiol. 2011, 82, 1359-1374. [CrossRef]

8. Dillon, S.C.; Dorman, C.J. Bacterial nucleoid-associated proteins, nucleoid structure and gene expression. Nat. Rev. Microbiol. 2010, 8, 185-195. [CrossRef]

9. Le, T.B.K.; Imakaev, M.V.; Mirny, L.A.; Laub, M.T. High-resolution mapping of the spatial organization of a bacterial chromosome. Science 2013, 342, 731-734. [CrossRef]

10. Reyes-Lamothe, R.; Sherratt, D.J. The bacterial cell cycle, chromosome inheritance and cell growth. Nat. Rev. Microbiol. 2019, 17, 467-478. [CrossRef]

11. Wang, X.; Montero Llopis, P.; Rudner, D.Z. Organization and segregation of bacterial chromosomes. Nat. Rev. Genet. 2013, 14, 191-203. [CrossRef] [PubMed]

12. Bouet, J.-Y.; Stouf, M.; Lebailly, E.; Cornet, F. Mechanisms for chromosome segregation. Curr. Opin. Microbiol. 2014, 22, 60-65. [CrossRef] [PubMed]

13. Valens, M.; Penaud, S.; Rossignol, M.; Cornet, F.; Boccard, F. Macrodomain organization of the Escherichia coli chromosome. EMBO J. 2004, 23, 4330-4341. [CrossRef] [PubMed] 
14. Dame, R.T.; Kalmykowa, O.J.; Grainger, D.C. Chromosomal macrodomains and associated proteins: Implications for DNA organization and replication in Gram-negative bacteria. PLoS Genet. 2011, 7, e1002123. [CrossRef] [PubMed]

15. Surovtsev, I.V.; Jacobs-Wagner, C. Subcellular organization: A critical feature of bacterial cell replication. Cell 2018, 172, 1271-1293. [CrossRef] [PubMed]

16. Marbouty, M.; Le Gall, A.; Cattoni, D.I.; Cournac, A.; Koh, A.; Fiche, J.-B.; Mozziconacci, J.; Murray, H.; Koszul, R.; Nollmann, M. Condensin- and replication-mediated bacterial chromosome folding and origin condensation revealed by Hi-C and super-resolution imaging. Mol. Cell 2015, 59, 588-602. [CrossRef] [PubMed]

17. Niki, H.; Yamaichi, Y.; Hiraga, S. Dynamic organization of chromosomal DNA in Escherichia coli. Genes Dev. 2000, 14, 212-223.

18. Espeli, O.; Mercier, R.; Boccard, F. DNA dynamics vary according to macrodomain topography in the E. coli chromosome. Mol. Microbiol. 2008, 68, 1418-1427. [CrossRef]

19. Dorman, C.J. Co-operative roles for DNA supercoiling and nucleoid-associated proteins in the regulation of bacterial transcription. Biochem. Soc. Trans. 2013, 41, 542-547. [CrossRef]

20. Val, M.-E.; Marbouty, M.; de Lemos Martins, F.; Kennedy, S.P.; Kemble, H.; Bland, M.J.; Possoz, C.; Koszul, R.; Skovgaard, O.; Mazel, D. A checkpoint control orchestrates the replication of the two chromosomes of Vibrio cholerae. Sci. Adv. 2016, 2, e1501914. [CrossRef]

21. Higgins, N.P. Species-specific supercoil dynamics of the bacterial nucleoid. Biophys. Rev. 2016, 8, 113-121. [CrossRef] [PubMed]

22. Le, T.B.; Laub, M.T. Transcription rate and transcript length drive formation of chromosomal interaction domain boundaries. EMBO J. 2016, 35, 1582-1595. [CrossRef] [PubMed]

23. Browning, D.F.; Grainger, D.C.; Busby, S.J. Effects of nucleoid-associated proteins on bacterial chromosome structure and gene expression. Curr. Opin. Microbiol. 2010, 13, 773-780. [CrossRef] [PubMed]

24. Lioy, V.S.; Cournac, A.; Marbouty, M.; Duigou, S.; Mozziconacci, J.; Espéli, O.; Boccard, F.; Koszul, R. Multiscale structuring of the E. coli chromosome by nucleoid-associated and condensin proteins. Cell 2018, 172, 771-783. [CrossRef]

25. Danilova, O.; Reyes-Lamothe, R.; Pinskaya, M.; Sherratt, D.; Possoz, C. MukB colocalizes with the oriC region and is required for organization of the two Escherichia coli chromosome arms into separate cell halves. Mol. Microbiol. 2007, 65, 1485-1492. [CrossRef]

26. Petrushenko, Z.M.; Cui, Y.; She, W.; Rybenkov, V.V. Mechanics of DNA bridging by bacterial condensin MukBEF in vitro and in singulo. EMBO J. 2010, 29, 1126-1135. [CrossRef]

27. Strunnikov, A.V. SMC complexes in bacterial chromosome condensation and segregation. Plasmid 2006, 55, 135-144. [CrossRef]

28. Wang, X.; Le, T.B.K.; Lajoie, B.R.; Dekker, J.; Laub, M.T.; Rudner, D.Z. Condensin promotes the juxtaposition of DNA flanking its loading site in Bacillus subtilis. Genes Dev. 2015, 29, 1661-1675. [CrossRef]

29. Trussart, M.; Yus, E.; Martinez, S.; Baù, D.; Tahara, Y.O.; Pengo, T.; Widjaja, M.; Kretschmer, S.; Swoger, J.; Djordjevic, S.; et al. Defined chromosome structure in the genome-reduced bacterium Mycoplasma pneumoniae. Nat. Commun. 2017, 8, 14665. [CrossRef]

30. Vallet-Gely, I.; Boccard, F. Chromosomal organization and segregation in Pseudomonas aeruginosa. PLoS Genet. 2013, 9, e1003492. [CrossRef]

31. Harms, A.; Treuner-Lange, A.; Schumacher, D.; Søgaard-Andersen, L. Tracking of chromosome and replisome dynamics in Myxococcus xanthus reveals a novel chromosome arrangement. PLoS Genet. 2013, 9, e1003802. [CrossRef]

32. Viollier, P.H.; Thanbichler, M.; McGrath, P.T.; West, L.; Meewan, M.; McAdams, H.H.; Shapiro, L. Rapid and sequential movement of individual chromosomal loci to specific subcellular locations during bacterial DNA replication. Proc. Natl. Acad. Sci. USA 2004, 101, 9257-9262. [CrossRef] [PubMed]

33. Umbarger, M.A.; Toro, E.; Wright, M.A.; Porreca, G.J.; Baù, D.; Hong, S.-H.; Fero, M.J.; Zhu, L.J.; Marti-Renom, M.A.; McAdams, H.H.; et al. The three-dimensional architecture of a bacterial genome and its alteration by genetic perturbation. Mol. Cell 2011, 44, 252-264. [CrossRef]

34. Marbouty, M.; Cournac, A.; Flot, J.-F.; Marie-Nelly, H.; Mozziconacci, J.; Koszul, R. Metagenomic chromosome conformation capture (meta3C) unveils the diversity of chromosome organization in microorganisms. ELife 2014, 3, e03318. [CrossRef] [PubMed] 
35. Nielsen, H.J.; Ottesen, J.R.; Youngren, B.; Austin, S.J.; Hansen, F.G. The Escherichia coli chromosome is organized with the left and right chromosome arms in separate cell halves. Mol. Microbiol. 2006, 62, 331-338. [CrossRef] [PubMed]

36. Wang, X.; Liu, X.; Possoz, C.; Sherratt, D.J. The two Escherichia coli chromosome arms locate to separate cell halves. Genes Dev. 2006, 20, 1727-1731. [CrossRef] [PubMed]

37. Nordström, K.; Molin, S.; Aagaard-Hansen, H. Partitioning of plasmid R1 in Escherichia coli: I. Kinetics of loss of plasmid derivatives deleted of the par region. Plasmid 1980, 4, 215-227. [CrossRef]

38. Austin, S.; Abeles, A. Partition of unit-copy miniplasmids to daughter cells. II. The partition region of miniplasmid P1 encodes an essential protein and a centromere-like site at which it acts. J. Mol. Biol. 1983, 169, 373-387. [CrossRef]

39. Abeles, A.L.; Friedman, S.A.; Austin, S.J. Partition of unit-copy miniplasmids to daughter cells. III. The DNA sequence and functional organization of the P1 partition region. J. Mol. Biol. 1985, 185, 261-272. [CrossRef]

40. Gerdes, K.; Larsen, J.E.; Molin, S. Stable inheritance of plasmid R1 requires two different loci. J. Bacteriol. 1985, 161, 292-298. [CrossRef]

41. Gerdes, K.; Møller-Jensen, J.; Jensen, R.B. Plasmid and chromosome partitioning: Surprises from phylogeny. Mol. Microbiol. 2000, 37, 455-466. [CrossRef] [PubMed]

42. Gerdes, K.; Howard, M.; Szardenings, F. Pushing and pulling in prokaryotic DNA segregation. Cell 2010, 141, 927-942. [CrossRef] [PubMed]

43. Hayes, F. The partition system of multidrug resistance plasmid TP228 includes a novel protein that epitomizes an evolutionarily distinct subgroup of the ParA superfamily. Mol. Microbiol. 2000, 37, 528-541. [CrossRef] [PubMed]

44. Motallebi-Veshareh, M.; Rouch, D.A.; Thomas, C.M. A family of ATPases involved in active partitioning of diverse bacterial plasmids. Mol. Microbiol. 1990, 4, 1455-1463. [CrossRef]

45. Koonin, E.V. A superfamily of ATPases with diverse functions containing either classical or deviant ATP-binding motif. J. Mol. Biol. 1993, 229, 1165-1174. [CrossRef]

46. Møller-Jensen, J.; Borch, J.; Dam, M.; Jensen, R.B.; Roepstorff, P.; Gerdes, K. Bacterial mitosis: ParM of plasmid R1 moves plasmid DNA by an actin-like insertional polymerization mechanism. Mol. Cell 2003, 12, 1477-1487. [CrossRef]

47. Larsen, R.A.; Cusumano, C.; Fujioka, A.; Lim-Fong, G.; Patterson, P.; Pogliano, J. Treadmilling of a prokaryotic tubulin-like protein, TubZ, required for plasmid stability in Bacillus thuringiensis. Genes Dev. 2007, 21, 1340-1352. [CrossRef]

48. Delbrück, H.; Ziegelin, G.; Lanka, E.; Heinemann, U. An Src homology 3-like domain is responsible for dimerization of the repressor protein KorB encoded by the promiscuous IncP plasmid RP4. J. Biol. Chem. 2002, 277, 4191-4198. [CrossRef]

49. Khare, D.; Ziegelin, G.; Lanka, E.; Heinemann, U. Sequence-specific DNA binding determined by contacts outside the helix-turn-helix motif of the ParB homolog KorB. Nat. Struct. Mol. Biol. 2004, 11, 656-663. [CrossRef]

50. Schumacher, M.A.; Mansoor, A.; Funnell, B.E. Structure of a four-way bridged ParB-DNA complex provides insight into P1 segrosome assembly. J. Biol. Chem. 2007, 282, 10456-10464. [CrossRef]

51. Schumacher, M.A.; Piro, K.M.; Xu, W. Insight into F plasmid DNA segregation revealed by structures of SopB and SopB-DNA complexes. Nucleic Acids Res. 2010, 38, 4514-4526. [CrossRef] [PubMed]

52. Golovanov, A.P.; Barillà, D.; Golovanova, M.; Hayes, F.; Lian, L.-Y. ParG, a protein required for active partition of bacterial plasmids, has a dimeric ribbon-helix-helix structure. Mol. Microbiol. 2003, 50, 1141-1153. [CrossRef] [PubMed]

53. Murayama, K.; Orth, P.; de la Hoz, A.B.; Alonso, J.C.; Saenger, W. Crystal structure of omega transcriptional repressor encoded by Streptococcus pyogenes plasmid pSM19035 at 1.5 A resolution. J. Mol. Biol. 2001, 314, 789-796. [CrossRef] [PubMed]

54. Barillà, D.; Carmelo, E.; Hayes, F. The tail of the ParG DNA segregation protein remodels ParF polymers and enhances ATP hydrolysis via an arginine finger-like motif. Proc. Natl. Acad. Sci. USA 2007, 104, 1811-1816. [CrossRef] [PubMed]

55. Ni, L.; Xu, W.; Kumaraswami, M.; Schumacher, M.A. Plasmid protein TubR uses a distinct mode of HTH-DNA binding and recruits the prokaryotic tubulin homolog TubZ to effect DNA partition. Proc. Natl. Acad. Sci. USA 2010, 107, 11763-11768. [CrossRef] [PubMed] 
56. Baxter, J.C.; Funnell, B.E. Plasmid partition mechanisms in Plasmids. In Biology and Impact in Biotechnology and Discovery; Tolmasky, M.E., Alonso, J.A., Eds.; ASM Press: Washington, DC, USA, 2015; pp. 135-155.

57. Schumacher, M.A. Bacterial plasmid partition machinery: A minimalist approach to survival. Curr. Opin. Struct. Biol. 2012, 22, 72-79. [CrossRef]

58. Ogasawara, N.; Yoshikawa, H. Genes and their organization in the replication origin region of the bacterial chromosome. Mol. Microbiol. 1992, 6, 629-634. [CrossRef] [PubMed]

59. Livny, J.; Yamaichi, Y.; Waldor, M.K. Distribution of centromere-like parS sites in bacteria: Insights from comparative genomics. J. Bacteriol. 2007, 189, 8693-8703. [CrossRef]

60. Gal-Mor, O.; Borovok, I.; Av-Gay, Y.; Cohen, G.; Aharonowitz, Y. Gene organization in the trxA/B-oriC region of the Streptomyces coelicolor chromosome and comparison with other eubacteria. Gene 1998, 217, 83-90. [CrossRef]

61. Lin, D.C.; Grossman, A.D. Identification and characterization of a bacterial chromosome partitioning site. Cell 1998, 92, 675-685. [CrossRef]

62. Yamaichi, Y.; Niki, H. Active segregation by the Bacillus subtilis partitioning system in Escherichia coli. Proc. Natl. Acad. Sci. USA 2000, 97, 14656-14661. [CrossRef] [PubMed]

63. Godfrin-Estevenon, A.-M.; Pasta, F.; Lane, D. The parAB gene products of Pseudomonas putida exhibit partition activity in both P. putida and Escherichia coli. Mol. Microbiol. 2002, 43, 39-49. [CrossRef] [PubMed]

64. Bartosik, A.A.; Lasocki, K.; Mierzejewska, J.; Thomas, C.M.; Jagura-Burdzy, G. ParB of Pseudomonas aeruginosa: Interactions with its partner ParA and its target parS and specific effects on bacterial growth. J. Bacteriol. 2004, 186, 6983-6998. [CrossRef] [PubMed]

65. Lemon, K.P.; Grossman, A.D. Localization of bacterial DNA polymerase: Evidence for a factory model of replication. Science 1998, 282, 1516-1519. [CrossRef] [PubMed]

66. Sawitzke, J.; Austin, S. An analysis of the factory model for chromosome replication and segregation in bacteria. Mol. Microbiol. 2001, 40, 786-794. [CrossRef] [PubMed]

67. Bartosik, A.A.; Jagura-Burdzy, G. Bacterial chromosome segregation. Acta Biochim. Pol. 2005, 52, 1-34. [CrossRef]

68. Breier, A.M.; Grossman, A.D. Whole-genome analysis of the chromosome partitioning and sporulation protein Spo0J (ParB) reveals spreading and origin-distal sites on the Bacillus subtilis chromosome. Mol. Microbiol. 2007, 64, 703-718. [CrossRef]

69. Ireton, K.; Gunther, N.W.; Grossman, A.D. spo0J is required for normal chromosome segregation as well as the initiation of sporulation in Bacillus subtilis. J. Bacteriol. 1994, 176, 5320-5329. [CrossRef]

70. Lee, P.S.; Grossman, A.D. The chromosome partitioning proteins Soj (ParA) and Spo0J (ParB) contribute to accurate chromosome partitioning, separation of replicated sister origins, and regulation of replication initiation in Bacillus subtilis. Mol. Microbiol. 2006, 60, 853-869. [CrossRef]

71. Minnen, A.; Attaiech, L.; Thon, M.; Gruber, S.; Veening, J.-W. SMC is recruited to oriC by ParB and promotes chromosome segregation in Streptococcus pneumoniae. Mol. Microbiol. 2011, 81, 676-688. [CrossRef]

72. Böhm, K.; Giacomelli, G.; Schmidt, A.; Imhof, A.; Koszul, R.; Marbouty, M.; Bramkamp, M. Chromosome organization by a conserved condensin-ParB system in the actinobacterium Corynebacterium glutamicum. bioRxiv 2019. [CrossRef]

73. Donovan, C.; Schwaiger, A.; Krämer, R.; Bramkamp, M. Subcellular localization and characterization of the ParAB system from Corynebacterium glutamicum. J. Bacteriol. 2010, 192, 3441-3451. [CrossRef] [PubMed]

74. Jakimowicz, D.; Brzostek, A.; Rumijowska-Galewicz, A.; Zydek, P.; Dołzbłasz, A.; Smulczyk-Krawczyszyn, A.; Zimniak, T.; Wojtasz, L.; Zawilak-Pawlik, A.; Kois, A.; et al. Characterization of the mycobacterial chromosome segregation protein ParB and identification of its target in Mycobacterium smegmatis. Microbiol. Read. Engl. 2007, 153, 4050-4060. [CrossRef] [PubMed]

75. Santi, I.; McKinney, J.D. Chromosome organization and replisome dynamics in Mycobacterium smegmatis. mBio 2015, 6, e01999-14. [CrossRef] [PubMed]

76. Jakimowicz, D.; Chater, K.; Zakrzewska-Czerwínska, J. The ParB protein of Streptomyces coelicolor A3(2) recognizes a cluster of parS sequences within the origin-proximal region of the linear chromosome. Mol. Microbiol. 2002, 45, 1365-1377. [CrossRef] [PubMed]

77. Kim, H.J.; Calcutt, M.J.; Schmidt, F.J.; Chater, K.F. Partitioning of the linear chromosome during sporulation of Streptomyces coelicolor A3(2) involves an oriC-linked parAB locus. J. Bacteriol. 2000, 182, 1313-1320. [CrossRef] [PubMed] 
78. Jakimowicz, D.; Zydek, P.; Kois, A.; Zakrzewska-Czerwińska, J.; Chater, K.F. Alignment of multiple chromosomes along helical ParA scaffolding in sporulating Streptomyces hyphae. Mol. Microbiol. 2007, 65, 625-641. [CrossRef]

79. Donczew, M.; Mackiewicz, P.; Wróbel, A.; Flärdh, K.; Zakrzewska-Czerwińska, J.; Jakimowicz, D. ParA and ParB coordinate chromosome segregation with cell elongation and division during Streptomyces sporulation. Open Biol. 2016, 6, 150263. [CrossRef]

80. Tran, N.T.; Stevenson, C.E.; Som, N.F.; Thanapipatsiri, A.; Jalal, A.S.B.; Le, T.B.K. Permissive zones for the centromere-binding protein ParB on the Caulobacter crescentus chromosome. Nucleic Acids Res. 2018, 46, 1196-1209. [CrossRef]

81. Toro, E.; Hong, S.-H.; McAdams, H.H.; Shapiro, L. Caulobacter requires a dedicated mechanism to initiate chromosome segregation. Proc. Natl. Acad. Sci. USA 2008, 105, 15435-15440. [CrossRef]

82. Mohl, D.A.; Easter, J.; Gober, J.W. The chromosome partitioning protein, ParB, is required for cytokinesis in Caulobacter crescentus. Mol. Microbiol. 2001, 42, 741-755. [CrossRef] [PubMed]

83. Jung, A.; Raßbach, A.; Pulpetta, R.L.; van Teeseling, M.C.F.; Heinrich, K.; Sobetzko, P.; Serrania, J.; Becker, A.; Thanbichler, M. Two-step chromosome segregation in the stalked budding bacterium Hyphomonas neptunium. Nat. Commun. 2019, 10, 3290. [CrossRef] [PubMed]

84. Dubarry, N.; Pasta, F.; Lane, D. ParABS systems of the four replicons of Burkholderia cenocepacia: New chromosome centromeres confer partition specificity. J. Bacteriol. 2006, 188, 1489-1496. [CrossRef] [PubMed]

85. Du, W.-L.; Dubarry, N.; Passot, F.M.; Kamgoué, A.; Murray, H.; Lane, D.; Pasta, F. Orderly Replication and segregation of the four replicons of Burkholderia cenocepacia J2315. PLoS Genet. 2016, 12, e1006172. [CrossRef] [PubMed]

86. Passot, F.M.; Calderon, V.; Fichant, G.; Lane, D.; Pasta, F. Centromere binding and evolution of chromosomal partition systems in the Burkholderiales. J. Bacteriol. 2012, 194, 3426-3436. [CrossRef]

87. Pillet, F.; Passot, F.M.; Pasta, F.; Anton Leberre, V.; Bouet, J.-Y. Analysis of ParB-centromere interactions by multiplex SPR imaging reveals specific patterns for binding ParB in six centromeres of Burkholderiales chromosomes and plasmids. PLoS ONE 2017, 12, e0177056. [CrossRef]

88. Iniesta, A.A. ParABS system in chromosome partitioning in the bacterium Myxococcus xanthus. PLoS ONE 2014, 9, e86897. [CrossRef]

89. Lagage, V.; Boccard, F.; Vallet-Gely, I. Regional control of chromosome segregation in Pseudomonas aeruginosa. PLoS Genet. 2016, 12, e1006428. [CrossRef]

90. Kawalek, A.; Bartosik, A.A.; Glabski, K.; Jagura-Burdzy, G. Pseudomonas aeruginosa partitioning protein ParB acts as a nucleoid-associated protein binding to multiple copies of a parS-related motif. Nucleic Acids Res. 2018, 46, 4592-4606. [CrossRef]

91. Jecz, P.; Bartosik, A.A.; Glabski, K.; Jagura-Burdzy, G. A single parS sequence from the cluster of four sites closest to oriC is necessary and sufficient for proper chromosome segregation in Pseudomonas aeruginosa. PLoS ONE 2015, 10, e0120867. [CrossRef]

92. Bartosik, A.A.; Mierzejewska, J.; Thomas, C.M.; Jagura-Burdzy, G. ParB deficiency in Pseudomonas aeruginosa destabilizes the partner protein ParA and affects a variety of physiological parameters. Microbiology 2009, 155, 1080-1092. [CrossRef]

93. Lewis, R.A.; Bignell, C.R.; Zeng, W.; Jones, A.C.; Thomas, C.M. Chromosome loss from par mutants of Pseudomonas putida depends on growth medium and phase of growth. Microbiology 2002, 148, 537-548. [CrossRef]

94. Yamaichi, Y.; Fogel, M.A.; McLeod, S.M.; Hui, M.P.; Waldor, M.K. Distinct centromere-like parS sites on the two chromosomes of Vibrio spp. J. Bacteriol. 2007, 189, 5314-5324. [CrossRef]

95. Kadoya, R.; Baek, J.H.; Sarker, A.; Chattoraj, D.K. Participation of chromosome segregation protein ParAI of Vibrio cholerae in chromosome replication. J. Bacteriol. 2011, 193, 1504-1514. [CrossRef]

96. Charaka, V.K.; Misra, H.S. Functional characterization of the role of the chromosome I partitioning system in genome segregation in Deinococcus radiodurans. J. Bacteriol. 2012, 194, 5739-5748. [CrossRef]

97. Li, H.; Angelov, A.; Pham, V.T.T.; Leis, B.; Liebl, W. Characterization of chromosomal and megaplasmid partitioning loci in Thermus thermophilus HB27. BMC Genomics 2015, 16, 317. [CrossRef]

98. Li, H. Random chromosome partitioning in the polyploid bacterium Thermus thermophilus HB27. G3 Genes Genomes Genet. 2019, 9, 1249-1261. [CrossRef] [PubMed] 
99. Mori, H.; Mori, Y.; Ichinose, C.; Niki, H.; Ogura, T.; Kato, A.; Hiraga, S. Purification and characterization of SopA and SopB proteins essential for F plasmid partitioning. J. Biol. Chem. 1989, 264, 15535-15541. [PubMed]

100. Hayes, F.; Radnedge, L.; Davis, M.A.; Austin, S.J. The homologous operons for P1 and P7 plasmid partition are autoregulated from dissimilar operator sites. Mol. Microbiol. 1994, 11, 249-260. [CrossRef] [PubMed]

101. Hester, C.M.; Lutkenhaus, J. Soj (ParA) DNA binding is mediated by conserved arginines and is essential for plasmid segregation. Proc. Natl. Acad. Sci. USA 2007, 104, 20326-20331. [CrossRef]

102. Chu, C.-H.; Yen, C.-Y.; Chen, B.-W.; Lin, M.-G.; Wang, L.-H.; Tang, K.-Z.; Hsiao, C.-D.; Sun, Y.-J. Crystal structures of HpSoj-DNA complexes and the nucleoid-adaptor complex formation in chromosome segregation. Nucleic Acids Res. 2019, 47, 2113-2129. [CrossRef]

103. Ptacin, J.L.; Lee, S.F.; Garner, E.C.; Toro, E.; Eckart, M.; Comolli, L.R.; Moerner, W.E.; Shapiro, L. A spindle-like apparatus guides bacterial chromosome segregation. Nat. Cell Biol. 2010, 12, 791-798. [CrossRef]

104. Figge, R.M.; Easter, J.; Gober, J.W. Productive interaction between the chromosome partitioning proteins, ParA and ParB, is required for the progression of the cell cycle in Caulobacter crescentus. Mol. Microbiol. 2003, 47, 1225-1237. [CrossRef] [PubMed]

105. Bartosik, A.A.; Glabski, K.; Jecz, P.; Lasocki, K.; Mikosa, M.; Plochocka, D.; Thomas, C.M.; Jagura-Burdzy, G. Dissection of the region of Pseudomonas aeruginosa ParA that is important for dimerization and interactions with its partner ParB. Microbiology 2014, 160, 2406-2420. [CrossRef] [PubMed]

106. Ringgaard, S.; Zon, J.; van Howard, M.; Gerdes, K. Movement and equipositioning of plasmids by ParA filament disassembly. Proc. Natl. Acad. Sci. USA 2009, 106, 19369-19374. [CrossRef]

107. Fogel, M.A.; Waldor, M.K. A dynamic, mitotic-like mechanism for bacterial chromosome segregation. Genes Dev. 2006, 20, 3269-3282. [CrossRef]

108. Hui, M.P.; Galkin, V.E.; Yu, X.; Stasiak, A.Z.; Stasiak, A.; Waldor, M.K.; Egelman, E.H. ParA2, a Vibrio cholerae chromosome partitioning protein, forms left-handed helical filaments on DNA. Proc. Natl. Acad. Sci. USA 2010, 107, 4590-4595. [CrossRef] [PubMed]

109. Lim, H.C.; Surovtsev, I.V.; Beltran, B.G.; Huang, F.; Bewersdorf, J.; Jacobs-Wagner, C. Evidence for a DNA-relay mechanism in ParABS-mediated chromosome segregation. Elife 2014, 3, e2758. [CrossRef] [PubMed]

110. Vecchiarelli, A.G.; Mizuuchi, K.; Funnell, B.E. Surfing biological surfaces: Exploiting the nucleoid for partition and transport in bacteria. Mol. Microbiol. 2012, 86, 513-523. [CrossRef]

111. Hwang, L.C.; Vecchiarelli, A.G.; Han, Y.-W.; Mizuuchi, M.; Harada, Y.; Funnell, B.E.; Mizuuchi, K. ParA-mediated plasmid partition driven by protein pattern self-organization. EMBO J. 2013, 32, 1238-1249. [CrossRef]

112. Kisner, J.R.; Kuwada, N.J. Nucleoid-mediated positioning and transport in bacteria. Curr. Genet. 2019. [CrossRef] [PubMed]

113. Brooks, A.C.; Hwang, L.C. Reconstitutions of plasmid partition systems and their mechanisms. Plasmid 2017, 91, 37-41. [CrossRef] [PubMed]

114. Kusiak, M.; Gapczyńska, A.; Płochocka, D.; Thomas, C.M.; Jagura-Burdzy, G. Binding and spreading of ParB on DNA determine its biological function in Pseudomonas aeruginosa. J. Bacteriol. 2011, 193, 3342-3355. [CrossRef] [PubMed]

115. Leonard, T.A.; Butler, P.J.G.; Löwe, J. Structural analysis of the chromosome segregation protein Spo0J from Thermus thermophilus. Mol. Microbiol. 2004, 53, 419-432. [CrossRef] [PubMed]

116. Chen, B.-W.; Lin, M.-H.; Chu, C.-H.; Hsu, C.-E.; Sun, Y.-J. Insights into ParB spreading from the complex structure of Spo0J and parS. Proc. Natl. Acad. Sci. USA 2015, 112, 6613-6618. [CrossRef] [PubMed]

117. Graham, T.G.W.; Wang, X.; Song, D.; Etson, C.M.; van Oijen, A.M.; Rudner, D.Z.; Loparo, J.J. ParB spreading requires DNA bridging. Genes Dev. 2014, 28, 1228-1238. [CrossRef] [PubMed]

118. Funnell, B.E. ParB partition proteins: Complex formation and spreading at bacterial and plasmid centromeres. Front. Mol. Biosci. 2016, 3, 44. [CrossRef]

119. Fisher, G.L.; Pastrana, C.L.; Higman, V.A.; Koh, A.; Taylor, J.A.; Butterer, A.; Craggs, T.; Sobott, F.; Murray, H.; Crump, M.P.; et al. The structural basis for dynamic DNA binding and bridging interactions which condense the bacterial centromere. ELife 2017, 6, e28086. [CrossRef]

120. Taylor, J.A.; Pastrana, C.L.; Butterer, A.; Pernstich, C.; Gwynn, E.J.; Sobott, F.; Moreno-Herrero, F.; Dillingham, M.S. Specific and non-specific interactions of ParB with DNA: Implications for chromosome segregation. Nucleic Acids Res. 2015, 43, 719-731. [CrossRef] 
121. Madariaga-Marcos, J.; Pastrana, C.L.; Fisher, G.L.; Dillingham, M.S.; Moreno-Herrero, F. ParB dynamics and the critical role of the CTD in DNA condensation unveiled by combined force-fluorescence measurements. ELife 2019, 8, e43812. [CrossRef]

122. Soh, Y.-M.; Davidson, I.F.; Zamuner, S.; Basquin, J.; Bock, F.P.; Taschner, M.; Veening, J.-W.; Rios, P.D.L.; Peters, J.-M.; Gruber, S. Self-organization of parS centromeres by the ParB CTP hydrolase. Science 2019, 366, 1129-1133. [CrossRef] [PubMed]

123. Lynch, A.S.; Wang, J.C. SopB protein-mediated silencing of genes linked to the sopC locus of Escherichia coli $\mathrm{F}$ plasmid. Proc. Natl. Acad. Sci. USA 1995, 92, 1896-1900. [CrossRef] [PubMed]

124. Rodionov, O.; Łobocka, M.; Yarmolinsky, M. Silencing of genes flanking the P1 plasmid centromere. Science 1999, 283, 546-549. [CrossRef] [PubMed]

125. Lukaszewicz, M.; Kostelidou, K.; Bartosik, A.A.; Cooke, G.D.; Thomas, C.M.; Jagura-Burdzy, G. Functional dissection of the ParB homologue (KorB) from IncP-1 plasmid RK2. Nucleic Acids Res. 2002, 30, 1046-1055. [CrossRef]

126. Bingle, L.E.H.; Macartney, D.P.; Fantozzi, A.; Manzoor, S.E.; Thomas, C.M. Flexibility in repression and cooperativity by KorB of broad host range IncP-1 plasmid RK2. J. Mol. Biol. 2005, 349, 302-316. [CrossRef]

127. Mohl, D.A.; Gober, J.W. Cell cycle-dependent polar localization of chromosome partitioning proteins in Caulobacter crescentus. Cell 1997, 88, 675-684. [CrossRef]

128. Lin, D.C.-H.; Levin, P.A.; Grossman, A.D. Bipolar localization of a chromosome partition protein in Bacillus subtilis. Proc. Natl. Acad. Sci. USA 1997, 94, 4721-4726. [CrossRef]

129. Debaugny, R.E.; Sanchez, A.; Rech, J.; Labourdette, D.; Dorignac, J.; Geniet, F.; Palmeri, J.; Parmeggiani, A.; Boudsocq, F.; Anton Leberre, V.; et al. A conserved mechanism drives partition complex assembly on bacterial chromosomes and plasmids. Mol. Syst. Biol. 2018, 14, e8516. [CrossRef]

130. Attaiech, L.; Minnen, A.; Kjos, M.; Gruber, S.; Veening, J.-W. The ParB-parS chromosome segregation system modulates competence development in Streptococcus pneumoniae. mBio 2015, 6, e00662. [CrossRef]

131. Glaser, P.; Sharpe, M.E.; Raether, B.; Perego, M.; Ohlsen, K.; Errington, J. Dynamic, mitotic-like behavior of a bacterial protein required for accurate chromosome partitioning. Genes Dev. 1997, 11, 1160-1168. [CrossRef]

132. Baek, J.H.; Rajagopala, S.V.; Chattoraj, D.K. Chromosome segregation proteins of Vibrio cholerae as transcription regulators. mBio 2014, 5, e01061-14. [CrossRef] [PubMed]

133. Jalal, A.S.B.; Pastrana, C.L.; Tran, N.T.; Stevenson, C.E.; Lawson, D.M.; Moreno-Herrero, F.; Le, T.B.K. Structural and biochemical analyses of Caulobacter crescentus ParB reveal the role of its N-terminal domain in chromosome segregation. bioRxiv 2019, 816959. [CrossRef]

134. Song, D.; Rodrigues, K.; Graham, T.G.W.; Loparo, J.J. A network of cis and trans interactions is required for ParB spreading. Nucleic Acids Res. 2017, 45, 7106-7117. [CrossRef] [PubMed]

135. Chaudhuri, B.N.; Dean, R. The evidence of large-scale DNA-induced compaction in the Mycobacterial chromosomal ParB. J. Mol. Biol. 2011, 413, 901-907. [CrossRef]

136. Broedersz, C.P.; Wang, X.; Meir, Y.; Loparo, J.J.; Rudner, D.Z.; Wingreen, N.S. Condensation and localization of the partitioning protein ParB on the bacterial chromosome. Proc. Natl. Acad. Sci. USA 2014, 111, 8809-8814. [CrossRef]

137. Audibert, S.; Gac, N.T.-L.; Rech, J.; Turlan, C.; Bouet, J.-Y.; Bystricky, K.; Lane, D. Role of centromere sites in activation of ParB proteins for partition complex assembly. bioRxiv 2019, 862136. [CrossRef]

138. Walter, J.-C.; Walliser, N.-O.; David, G.; Dorignac, J.; Geniet, F.; Palmeri, J.; Parmeggiani, A.; Wingreen, N.S.; Broedersz, C.P. Looping and clustering model for the organization of protein-DNA complexes on the bacterial genome. N. J. Phys. 2018, 20, e035002. [CrossRef]

139. Sanchez, A.; Cattoni, D.I.; Walter, J.-C.; Rech, J.; Parmeggiani, A.; Nollmann, M.; Bouet, J.-Y. Stochastic Self-Assembly of ParB proteins builds the bacterial DNA segregation apparatus. Cell Syst. 2015, 1, 163-173. [CrossRef]

140. Jalal, A.S.B.; Tran, N.T.; Le, T.B.K. ParB spreading on DNA requires cytidine triphosphate in vitro. bioRxiv 2019, 865972. [CrossRef]

141. Osorio-Valeriano, M.; Altegoer, F.; Steinchen, W.; Urban, S.; Liu, Y.; Bange, G.; Thanbichler, M. ParB-type DNA segregation proteins are CTP-dependent molecular switches. Cell 2019, 179, 1512-1524.e15. [CrossRef]

142. Jalal, A.S.B.; Tran, N.T.; Stevenson, C.E.; Tan, X.; Lawson, D.M.; Le, T.B.K. Evolving a new protein-DNA interface via sequential introduction of permissive and specificity-switching mutations. bioRxiv 2019, 724823. [CrossRef] 
143. Chen, S.; Zhou, Y.; Chen, Y.; Gu, J. Fastp: An ultra-fast all-in-one FASTQ preprocessor. Bioinformatics 2018, 34, i884-i890. [CrossRef]

144. Langmead, B.; Salzberg, S.L. Fast gapped-read alignment with Bowtie 2. Nat. Methods 2012, 9, 357-359. [CrossRef] [PubMed]

145. Li, H. A statistical framework for SNP calling, mutation discovery, association mapping and population genetical parameter estimation from sequencing data. Bioinforma. Oxf. Engl. 2011, 27, 2987-2993. [CrossRef] [PubMed]

146. Ramírez, F.; Ryan, D.P.; Grüning, B.; Bhardwaj, V.; Kilpert, F.; Richter, A.S.; Heyne, S.; Dündar, F.; Manke, T. deepTools2: A next generation web server for deep-sequencing data analysis. Nucleic Acids Res. 2016, 44, W160-W165. [CrossRef] [PubMed]

147. Yuen, K.C.; Gerton, J.L. Taking cohesin and condensin in context. PLoS Genet. 2018, 14, e1007118. [CrossRef] [PubMed]

148. Minnen, A.; Bürmann, F.; Wilhelm, L.; Anchimiuk, A.; Diebold-Durand, M.-L.; Gruber, S. Control of Smc coiled coil architecture by the ATPase heads facilitates targeting to chromosomal ParB/parS and release onto flanking DNA. Cell Rep. 2016, 14, 2003-2016. [CrossRef]

149. Wang, X.; Brandão, H.B.; Le, T.B.K.; Laub, M.T.; Rudner, D.Z. Bacillus subtilis SMC complexes juxtapose chromosome arms as they travel from origin to terminus. Science 2017, 355, 524-527. [CrossRef]

150. Hirano, T. At the heart of the chromosome: SMC proteins in action. Nat. Rev. Mol. Cell Biol. 2006, 7, 311-322. [CrossRef]

151. Tran, N.T.; Laub, M.T.; Le, T.B.K. SMC Progressively aligns chromosomal arms in Caulobacter crescentus but is antagonized by convergent transcription. Cell Rep. 2017, 20, 2057-2071. [CrossRef]

152. Wilhelm, L.; Bürmann, F.; Minnen, A.; Shin, H.-C.; Toseland, C.P.; Oh, B.-H.; Gruber, S. SMC condensin entraps chromosomal DNA by an ATP hydrolysis dependent loading mechanism in Bacillus subtilis. eLife 2015, 4, e06659. [CrossRef]

153. Hassler, M.; Shaltiel, I.A.; Kschonsak, M.; Simon, B.; Merkel, F.; Thärichen, L.; Bailey, H.J.; Macošek, J.; Bravo, S.; Metz, J.; et al. Structural basis of an asymmetric condensin ATPase cycle. Mol. Cell 2019, 74, 1175-1188. [CrossRef] [PubMed]

154. Gruber, S. SMC complexes sweeping through the chromosome: Going with the flow and against the tide. Curr. Opin. Microbiol. 2018, 42, 96-103. [CrossRef]

155. Nolivos, S.; Upton, A.L.; Badrinarayanan, A.; Müller, J.; Zawadzka, K.; Wiktor, J.; Gill, A.; Arciszewska, L.; Nicolas, E.; Sherratt, D. MatP regulates the coordinated action of topoisomerase IV and MukBEF in chromosome segregation. Nat. Commun. 2016, 7, 10466. [CrossRef] [PubMed]

156. Zhao, H.; Clevenger, A.L.; Ritchey, J.W.; Zgurskaya, H.I.; Rybenkov, V.V. Pseudomonas aeruginosa condensins support opposite differentiation states. J. Bacteriol. 2016, 198, 2936-2944. [CrossRef] [PubMed]

157. Panas, M.W.; Jain, P.; Yang, H.; Mitra, S.; Biswas, D.; Wattam, A.R.; Letvin, N.L.; Jacobs, W.R. Noncanonical SMC protein in Mycobacterium smegmatis restricts maintenance of Mycobacterium fortuitum plasmids. Proc. Natl. Acad. Sci. USA 2014, 111, 13264-13271. [CrossRef]

158. Szafran, M.; Skut, P.; Ditkowski, B.; Ginda, K.; Chandra, G.; Zakrzewska-Czerwińska, J.; Jakimowicz, D. Topoisomerase I (TopA) is recruited to ParB complexes and is required for proper chromosome organization during Streptomyces coelicolor sporulation. J. Bacteriol. 2013, 195, 4445-4455. [CrossRef]

159. Champoux, J.J. DNA topoisomerases: Structure, function, and mechanism. Annu. Rev. Biochem. 2001, 70, 369-413. [CrossRef]

160. Murray, H.; Errington, J. Dynamic control of the DNA replication initiation protein DnaA by Soj/ParA. Cell 2008, 135, 74-84. [CrossRef]

161. Scholefield, G.; Whiting, R.; Errington, J.; Murray, H. Spo0J regulates the oligomeric state of Soj to trigger its switch from an activator to an inhibitor of DNA replication initiation. Mol. Microbiol. 2011, 79, 1089-1100. [CrossRef]

162. Scholefield, G.; Errington, J.; Murray, H. Soj/ParA stalls DNA replication by inhibiting helix formation of the initiator protein DnaA. EMBO J. 2012, 31, 1542-1555. [CrossRef] [PubMed]

163. Maurya, G.K.; Kota, S.; Misra, H.S. Characterisation of ParB encoded on multipartite genome in Deinococcus radiodurans and their roles in radioresistance. Microbiol. Res. 2019, 223, 22-32. [CrossRef]

164. Perry, S.E.; Edwards, D.H. The Bacillus subtilis DivIVA protein has a sporulation-specific proximity to Spo0J. J. Bacteriol. 2006, 188, 6039-6043. [CrossRef] [PubMed] 
165. Lin, L.; Osorio Valeriano, M.; Harms, A.; Søgaard-Andersen, L.; Thanbichler, M. Bactofilin-mediated organization of the ParABS chromosome segregation system in Myxococcus xanthus. Nat. Commun. 2017, 8 , 1817. [CrossRef] [PubMed]

166. Ginda, K.; Bezulska, M.; Ziółkiewicz, M.; Dziadek, J.; Zakrzewska-Czerwińska, J.; Jakimowicz, D. ParA of Mycobacterium smegmatis co-ordinates chromosome segregation with the cell cycle and interacts with the polar growth determinant DivIVA. Mol. Microbiol. 2013, 87, 998-1012. [CrossRef]

167. Pióro, M.; Małecki, T.; Portas, M.; Magierowska, I.; Trojanowski, D.; Sherratt, D.; Zakrzewska-Czerwińska, J.; Ginda, K.; Jakimowicz, D. Competition between DivIVA and the nucleoid for ParA binding promotes segrosome separation and modulates mycobacterial cell elongation. Mol. Microbiol. 2019, 111, 204-220. [CrossRef]

168. Nourikyan, J.; Kjos, M.; Mercy, C.; Cluzel, C.; Morlot, C.; Noirot-Gros, M.-F.; Guiral, S.; Lavergne, J.-P.; Veening, J.-W.; Grangeasse, C. Autophosphorylation of the bacterial tyrosine-kinase CpsD connects capsule synthesis with the cell cycle in Streptococcus pneumoniae. PLoS Genet. 2015, 11, e1005518. [CrossRef]

169. Fadda, D.; Santona, A.; D’Ulisse, V.; Ghelardini, P.; Ennas, M.G.; Whalen, M.B.; Massidda, O. Streptococcus pneumoniae DivIVA: Localization and interactions in a MinCD-free context. J. Bacteriol. 2007, 189, 1288-1298. [CrossRef]

170. Mercy, C.; Ducret, A.; Slager, J.; Lavergne, J.-P.; Freton, C.; Nagarajan, S.N.; Garcia, P.S.; Noirot-Gros, M.-F.; Dubarry, N.; Nourikyan, J.; et al. RocS drives chromosome segregation and nucleoid protection in Streptococcus pneumoniae. Nat. Microbiol. 2019, 4, 1661-1670. [CrossRef]

171. Kois-Ostrowska, A.; Strzałka, A.; Lipietta, N.; Tilley, E.; Zakrzewska-Czerwińska, J.; Herron, P.; Jakimowicz, D. Unique function of the bacterial chromosome segregation machinery in apically growing Streptomyces-targeting the chromosome to new hyphal tubes and its anchorage at the tips. PLoS Genet. 2016, 12, e1006488. [CrossRef]

172. Ditkowski, B.; Troć, P.; Ginda, K.; Donczew, M.; Chater, K.F.; Zakrzewska-Czerwińska, J.; Jakimowicz, D. The actinobacterial signature protein ParJ (SCO1662) regulates ParA polymerization and affects chromosome segregation and cell division during Streptomyces sporulation. Mol. Microbiol. 2010, 78, 1403-1415. [CrossRef] [PubMed]

173. Ditkowski, B.; Holmes, N.; Rydzak, J.; Donczew, M.; Bezulska, M.; Ginda, K.; Kedzierski, P.; Zakrzewska-Czerwińska, J.; Kelemen, G.H.; Jakimowicz, D. Dynamic interplay of ParA with the polarity protein, Scy, coordinates the growth with chromosome segregation in Streptomyces coelicolor. Open Biol. 2013, 3, 130006. [CrossRef] [PubMed]

174. Shebelut, C.W.; Guberman, J.M.; Teeffelen, S.; van Yakhnina, A.A.; Gitai, Z. Caulobacter chromosome segregation is an ordered multistep process. Proc. Natl. Acad. Sci. USA 2010, 107, 14194-14198. [CrossRef] [PubMed]

175. Bowman, G.R.; Comolli, L.R.; Zhu, J.; Eckart, M.; Koenig, M.; Downing, K.H.; Moerner, W.E.; Earnest, T.; Shapiro, L. A polymeric protein anchors the chromosomal origin/ParB complex at a bacterial cell pole. Cell 2008, 134, 945-955. [CrossRef] [PubMed]

176. Ptacin, J.L.; Gahlmann, A.; Bowman, G.R.; Perez, A.M.; von Diezmann, A.R.S.; Eckart, R.M.; Moerner, W.E.; Shapiro, L. Bacterial scaffold directs pole-specific centromere segregation. Proc. Natl. Acad. Sci. USA 2014, 111, 2046-2055. [CrossRef]

177. Thanbichler, M.; Shapiro, L. MipZ, A spatial regulator coordinating chromosome segregation with cell division in Caulobacter. Cell 2006, 126, 147-162. [CrossRef]

178. Schofield, W.B.; Lim, H.C.; Jacobs-Wagner, C. Cell cycle coordination and regulation of bacterial chromosome segregation dynamics by polarly localized proteins. EMBO J. 2010, 29, 3068-3081. [CrossRef]

179. Charaka, V.; Kota, S.; Misra, H. ParA encoded on chromosome i of Deinococcus radiodurans requires its cognate ParB and centromere for its dynamics. Proc. Indian Natl. Sci. Acad. 2014, 80, 663. [CrossRef]

180. Maurya, G.K.; Modi, K.; Misra, H.S. Divisome and segrosome components of Deinococcus radiodurans interact through cell division regulatory proteins. Microbiol. Read. Engl. 2016, 162, 1321-1334. [CrossRef]

181. Chaudhary, R.; Gupta, A.; Kota, S.; Misra, H.S. N-terminal domain of DivIVA contributes to its dimerization and interaction with genome segregation proteins in a radioresistant bacterium Deinococcus radiodurans. Int. J. Biol. Macromol. 2019, 128, 12-21. [CrossRef] 
182. Yamaichi, Y.; Bruckner, R.; Ringgaard, S.; Möll, A.; Cameron, D.E.; Briegel, A.; Jensen, G.J.; Davis, B.M.; Waldor, M.K. A multidomain hub anchors the chromosome segregation and chemotactic machinery to the bacterial pole. Genes Dev. 2012, 26, 2348-2360. [CrossRef] [PubMed]

183. Dubarry, N.; Willis, C.R.; Ball, G.; Lesterlin, C.; Armitage, J.P. In vivo imaging of the segregation of the 2 chromosomes and the cell division proteins of Rhodobacter sphaeroides reveals an unexpected role for MipZ. mBio 2019, 10, e02515-e02518. [CrossRef] [PubMed]

184. Toro-Nahuelpan, M.; Corrales-Guerrero, L.; Zwiener, T.; Osorio-Valeriano, M.; Müller, F.-D.; Plitzko, J.M.; Bramkamp, M.; Thanbichler, M.; Schüler, D. A gradient-forming MipZ protein mediating the control of cell division in the magnetotactic bacterium Magnetospirillum gryphiswaldense. Mol. Microbiol. 2019, 112, 1423-1439. [CrossRef] [PubMed]

185. Errington, J.; Wu, L.J. Cell cycle machinery in Bacillus subtilis. Subcell. Biochem. 2017, 84, 67-101. [PubMed]

186. van Baarle, S.; Bramkamp, M. The MinCDJ system in Bacillus subtilis prevents minicell formation by promoting divisome disassembly. PLoS ONE 2010, 5, e9850. [CrossRef]

187. Sievers, J.; Raether, B.; Perego, M.; Errington, J. Characterization of the parB-like yyaA gene of Bacillus subtilis. J. Bacteriol. 2002, 184, 1102-1111. [CrossRef]

188. Wu, L.J.; Ishikawa, S.; Kawai, Y.; Oshima, T.; Ogasawara, N.; Errington, J. Noc protein binds to specific DNA sequences to coordinate cell division with chromosome segregation. EMBO J. 2009, 28, 1940-1952. [CrossRef]

189. Adams, D.W.; Wu, L.J.; Errington, J. Nucleoid occlusion protein Noc recruits DNA to the bacterial cell membrane. EMBO J. 2015, 34, 491-501. [CrossRef]

190. Hajduk, I.V.; Mann, R.; Rodrigues, C.D.A.; Harry, E.J. The ParB homologs, Spo0J and Noc, together prevent premature midcell $\mathrm{Z}$ ring assembly when the early stages of replication are blocked in Bacillus subtilis. Mol. Microbiol. 2019, 112, 766-784. [CrossRef]

191. Hammond, L.R.; White, M.L.; Eswara, P.J. ¡vIVA la DivIVA! J. Bacteriol. 2019, 201, e00245-19. [CrossRef]

192. Bergé, M.; Viollier, P.H. End-in-sight: Cell polarization by the polygamic organizer PopZ. Trends Microbiol. 2018, 26, 363-375. [CrossRef] [PubMed]

193. Marczynski, G.T.; Petit, K.; Patel, P. Crosstalk regulation between bacterial chromosome replication and chromosome partitioning. Front. Microbiol. 2019, 10, 279. [CrossRef]

194. Ausmees, N.; Kuhn, J.R.; Jacobs-Wagner, C. The bacterial cytoskeleton: An intermediate filament-like function in cell shape. Cell 2003, 115, 705-713. [CrossRef]

195. Refes, Y.; He, B.; Corrales-Guerrero, L.; Steinchen, W.; Panis, G.; Viollier, P.H.; Bange, G.; Thanbichler, M. Molecular architecture of the DNA-binding sites of the P-loop ATPases MipZ and ParA from Caulobacter crescentus. bioRxiv 2019, 766287. [CrossRef]

196. Kiekebusch, D.; Michie, K.A.; Essen, L.-O.; Löwe, J.; Thanbichler, M. Localized dimerization and nucleoid binding drive gradient formation by the bacterial cell division inhibitor MipZ. Mol. Cell 2012, 46, 245-259. [CrossRef] [PubMed]

197. Tettelin, H.; Nelson, K.E.; Paulsen, I.T.; Eisen, J.A.; Read, T.D.; Peterson, S.; Heidelberg, J.; DeBoy, R.T.; Haft, D.H.; Dodson, R.J.; et al. Complete genome sequence of a virulent isolate of Streptococcus pneumoniae. Science 2001, 293, 498-506. [CrossRef] [PubMed]

198. Thomas, C.M.; Smith, C.A.; Shingler, V.; Cross, M.A.; Hussain, A.A.; Pinkney, M. Regulation of replication and maintenance functions of broad host-range plasmid RK2. Basic Life Sci. 1985, 30, 261-276.

199. Jagura-Burdzy, G.; Kostelidou, K.; Pole, J.; Khare, D.; Jones, A.; Williams, D.R.; Thomas, C.M. IncC of broad-host-range plasmid RK2 modulates KorB transcriptional repressor activity in vivo and operator binding in vitro. J. Bacteriol. 1999, 181, 2807-2815. [CrossRef]

200. Kulinska, A.; Godziszewska, J.; Wojciechowska, A.; Ludwiczak, M.; Jagura-Burdzy, G. Global transcriptional regulation of backbone genes in broad-host-range plasmid RA3 from the IncU group involves segregation protein KorB (ParB family). Appl. Environ. Microbiol. 2016, 82, 2320-2335. [CrossRef]

201. Bartosik, A.A.; Glabski, K.; Jecz, P.; Mikulska, S.; Fogtman, A.; Koblowska, M.; Jagura-Burdzy, G. Transcriptional profiling of ParA and ParB mutants in actively dividing cells of an opportunistic human pathogen Pseudomonas aeruginosa. PLoS ONE 2014, 9, e87276. [CrossRef]

202. Lasocki, K.; Bartosik, A.A.; Mierzejewska, J.; Thomas, C.M.; Jagura-Burdzy, G. Deletion of the parA (soj) homologue in Pseudomonas aeruginosa causes ParB instability and affects growth rate, chromosome segregation, and motility. J. Bacteriol. 2007, 189, 5762-5772. [CrossRef] [PubMed] 
203. Kawalek, A.; Glabski, K.; Bartosik, A.A.; Fogtman, A.; Jagura-Burdzy, G. Increased ParB level affects expression of stress response, adaptation and virulence operons and potentiates repression of promoters adjacent to the high affinity binding sites parS3 and parS4 in Pseudomonas aeruginosa. PLoS ONE 2017, 12, e0181726. [CrossRef] [PubMed]

204. Jun, S.; Wright, A. Entropy as the driver of chromosome segregation. Nat. Rev. Microbiol. 2010, 8, 600-607. [CrossRef] [PubMed]

205. Jun, S.; Mulder, B. Entropy-driven spatial organization of highly confined polymers: Lessons for the bacterial chromosome. Proc. Natl. Acad. Sci. USA 2006, 103, 12388-12393. [CrossRef]

206. Weber, P.M.; Moessel, F.; Paredes, G.F.; Viehboeck, T.; Vischer, N.O.E.; Bulgheresi, S. A Bidimensional segregation mode maintains symbiont chromosome orientation toward its host. Curr. Biol. 2019, 29, 3018-3028. [CrossRef]

207. Jakimowicz, D.; Mouz, S.; Zakrzewska-Czerwinska, J.; Chater, K.F. Developmental control of a parAB promoter leads to formation of sporulation-associated ParB complexes in Streptomyces coelicolor. J. Bacteriol. 2006, 188, 1710-1720. [CrossRef]

208. Casart, Y.; Gamero, E.; Rivera-Gutierrez, S.; González-y-Merchand, J.A.; Salazar, L. par genes in Mycobacterium bovis and Mycobacterium smegmatis are arranged in an operon transcribed from "SigGC" promoters. BMC Microbiol. 2008, 8, 51. [CrossRef]

209. Manuse, S.; Fleurie, A.; Zucchini, L.; Lesterlin, C.; Grangeasse, C. Role of eukaryotic-like serine/threonine kinases in bacterial cell division and morphogenesis. FEMS Microbiol. Rev. 2016, 40, 41-56. [CrossRef]

210. Janczarek, M.; Vinardell, J.-M.; Lipa, P.; Karaś, M. Hanks-type serine/threonine protein kinases and phosphatases in bacteria: Roles in signaling and adaptation to various environments. Int. J. Mol. Sci. 2018, 19, e2872. [CrossRef]

211. Carabetta, V.J.; Cristea, I.M. Regulation, function, and detection of protein acetylation in bacteria. J. Bacteriol. 2017, 199, e00107-e00117. [CrossRef]

212. Baronian, G.; Ginda, K.; Berry, L.; Cohen-Gonsaud, M.; Zakrzewska-Czerwińska, J.; Jakimowicz, D.; Molle, V. Phosphorylation of Mycobacterium tuberculosis ParB participates in regulating the ParABS chromosome segregation system. PLoS ONE 2015, 10, e0119907. [CrossRef] [PubMed]

213. Chawla, Y.; Upadhyay, S.; Khan, S.; Nagarajan, S.N.; Forti, F.; Nandicoori, V.K. Protein kinase B (PknB) of Mycobacterium tuberculosis is essential for growth of the pathogen in vitro as well as for survival within the host. J. Biol. Chem. 2014, 289, 13858-13875. [CrossRef] [PubMed] 